\title{
Synthesis and Antiinflammatory Activity of 7-Methanesulfonylamino- 6-phenoxychromones. Antiarthritic Effect of the 3-Formylamino Compound (T-614) in Chronic Inflammatory Disease Models
}

\author{
Takihiro Inaba, Keiichi Tanaka, ${ }^{*}$ RyukoTakeno, Hideyoshi Nagaki, Chosaku Yoshida, and \\ Shuntaro TAKANO
}

Research Laboratories, Toyama Chemical Co., Ltd., Shimookui 2-4-1, Toyama 930-8508, Japan.

Received August 11, 1999; accepted September 24, 1999

\begin{abstract}
A group of derivatives of 7-methanesulfonylamino-6-phenoxychromone (1) at the pyrone and phenoxy rings was synthesized starting with 4-chloro-3-nitroanisole and evaluated against acute and chronic inflammations in oral administration in animals. Significant potency in the rat models of carrageenin-induced edema (CPE) and adjuvant-induced arthritis (AA) was realized with $2^{\prime}$-fluoro and $2^{\prime}, 4^{\prime}$-diffuoro derivatives (9a and 9d), and 3formylamino derivative (19a) and its $2^{\prime}$-fluoro and $2^{\prime}, 4^{\prime}$-difluoro compounds (22a and 22d), displaying AA therapeutic effect of $\mathrm{ED}_{40}=2.5-7.1 \mathrm{mg} / \mathrm{kg} / \mathrm{d}$ for $7 \mathrm{~d}$ and $\mathrm{AA}$ prophylactic effect of $53-70 \%$ inhibition at the dosage of $3 \mathrm{mg} / \mathrm{kg} / \mathrm{d}$ for $22 \mathrm{~d}$. To identify a candidate for further pharmacological study, the five compounds were subjected to evaluation of their gastro-ulcerogenic liability, leading to selection of the fluorine-free compound 19a which did not cause acute ulceration at $300 \mathrm{mg} / \mathrm{kg}$ in oral administration in rats. Compound $19 \mathrm{a}\left(\mathrm{ED}_{40}=3.6 \mathrm{mg} / \mathrm{kg}\right.$ in established AA) possessed good therapeutic efficacy against type II collagen-induced arthritis in DBA/1J mice with doses of 30 and $100 \mathrm{mg} / \mathrm{kg}$, suggesting the development of 19a (designated T-614) as a prospective diseasemodifying antirheumatic agent. In addition, a preparative-scale synthetic route to T-614 has been established.
\end{abstract} 614

Key words antiinflammatory activity; methanesulfoanilide; chromone; structure-activity relationship; antiarthritic activity; T-

The majority of currently marketed nonsteroidal antiinflammatory drugs (NSAIDs) are chemically hydroxylic acids as represented by indomethacin and ibuprofen (carboxylic) and piroxicam (enolic). These NSAIDs are believed to exhibit their antiinflammatory activity by inhibiting the enzyme cyclooxygenase (COX) that catalyzes the biosynthesis of prostaglandins and thromboxane from arachidonic acid, the mechanism correlated with unwanted side-effects such as gastrointestinal and renal toxicity. ${ }^{1)}$ It was in the mid-1970s that R-805, or nimesulide [ $N$-(4-nitro-2-phenoxyphenyl)methanesulfonamide] was reported by Swingle $e t a l{ }^{2)}$ as the first member of the methanesulfoanilide class of NSAID $\left(\mathrm{N}-\mathrm{H}\right.$ acid of $\mathrm{p} K_{\mathrm{a}} 6-7$ ), which was characterized by low gastrointestinal toxicity in conventional animal models. Since then, structural modifications of nimesulide aimed at enhancing its antiinflammatory activity and reducing the toxicity have been carried out by other groups to yield some advanced agents such as flosulide (CGP-28238), ${ }^{3)}$ NS-398 (2cyclohexyloxy analogue of nimesulide), ${ }^{4)}$ and FK-3311 ${ }^{5)}$ (Chart 1). These new sulfoanilides which proved more potent and yet less ulcerogenic than nimesulide were subsequently demonstrated to display selective inhibition of the inducible cyclooxygenase (COX-2) upregulated at inflammatory sites without affecting the constitutive COX-1 which is associated with homeostatic prostanoid synthesis. Unexpectedly, however, subsequent testing with NS-398 and flosulide has revealed that the classical NSAID-like ulcerogenic liability is still an issue and these two are not being developed further. ${ }^{6)}$

In our study aimed at developing an advanced sulfoanilide antiinflammatory agent, we designed the methanesulfoanilides having chromone and 2,3-dihydrochromone rings, particularly compound $\mathbf{1}$ or $\mathbf{2}$ (Chart 1 ) as a lead structure in which the amide nitrogen is located at the para position with respect to the carbonyl group as seen in the structures of flo- sulide and FK-3311. Conventional assays for antiinflammatory activity and ulcerogenicity liability in animal models proved that the chromone compound $\mathbf{1}$ deserves to receive structural modifications (Table 1). Accordingly, derivatives of $\mathbf{1}$ at the phenoxy ring as well as at the pyrone ring were synthesized and their structure-activity relationship studied in terms of inhibition of rat carrageenin-induced paw edema and rat adjuvant-induced arthritis, in addition to ulcerogenic liability. The best pharmacological profile has been obtained with $N$-(3-formylamino-4-oxo-6-phenoxy-4H-7-chromenyl)methanesulfonamide, which was designated as T-614. ${ }^{7)}$ This paper describes the synthesis of a series of derivatives of 1 and the details of their structure-activity relationship leading to our assignment of T-614 for further investigation as an antiarthritis agent. In addition, a preparative-scale synthetic route to T-614 has been investigated.

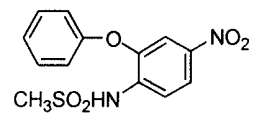

Nimesulide (R-805)

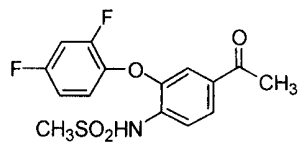

FK-3311

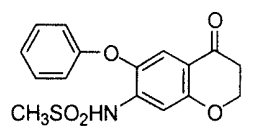

2

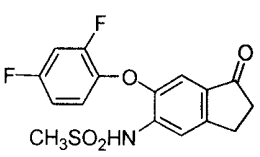

Flosulide (CGP-28238)

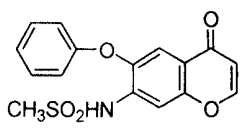

1

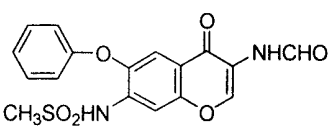

T-614
Chart 1

(C) 2000 Pharmaceutical Society of Japan 


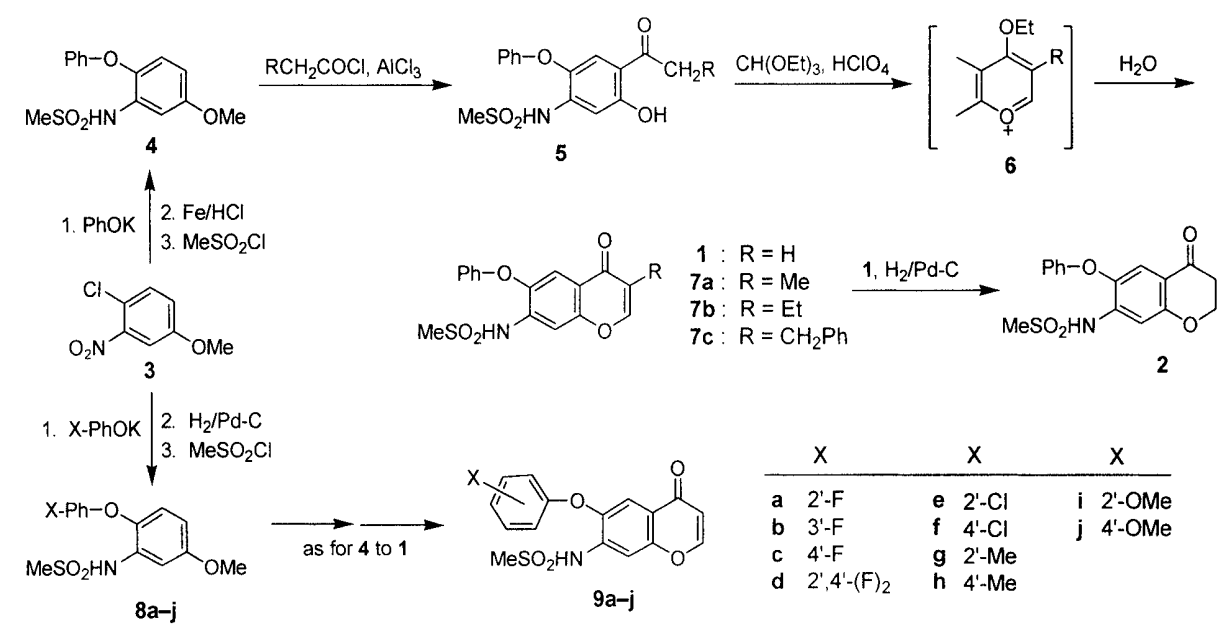

Chart 2

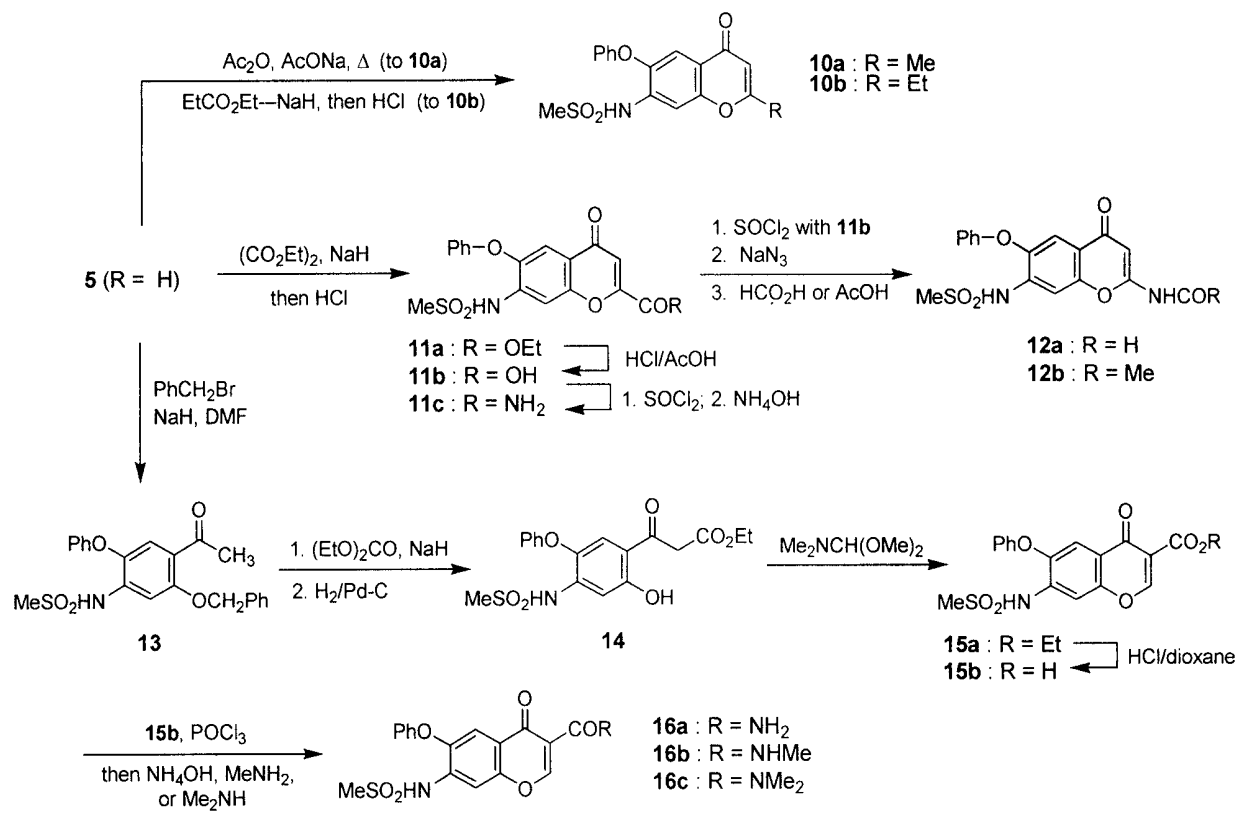

Chart 3

\section{Chemistry}

$\mathrm{N}$-(4-Oxo-6-phenoxy-4H-7-chromenyl)methanesulfonamide (1) and its 2,3-dihydro compound (2) were synthesized starting with commercially available 4-chloro-3-nitroanisole (3) (Chart 2). Reaction of $\mathbf{3}$ with phenol in the presence of tert-BuOK in hot $N, N$-dimethylformamide (DMF) afforded 3-nitro-4-phenoxyanisole, ${ }^{8)}$ which was converted to the sulfonamide 4 by reduction of the nitro group with iron powder followed by $N$-sulfonylation with methanesulfonyl chloride in pyridine (an overall yield of 50\%). Friedel-Crafts acylation of $\mathbf{4}$ with acetyl chloride in dichloromethane using 2 equivalents of $\mathrm{AlCl}_{3}$ afforded 2'-hydroxyacetophenone compound $(5, \mathrm{R}=\mathrm{H})$ in $84 \%$ yield. This product was then subjected to the pyrone-ring annulation with triethyl orthoformate in the presence of perchloric acid to yield a benzopyrylium salt $6,{ }^{9}$ ) which on treatment with hot water provided 1 in $85 \%$ yield. Catalytic hydrogenation of $\mathbf{1}$ in the presence of $\mathrm{Pd}-\mathrm{C}$ in acetic acid afforded 2. 3Alkyl derivatives of $\mathbf{1}(\mathbf{7 a}-\mathbf{c})$ were obtained from 4 by using appropriate acyl chlorides $\left(\mathrm{RCH}_{2} \mathrm{COCl}\right)$ in the Friedel-Crafts acylation step. The chromones $9 \mathbf{a}-\mathbf{j}$ having substituted phenoxy group at the 6-position were similarly prepared via intermediacy of $8 \mathbf{a}-\mathbf{j}$ obtained by the displacement reaction of 3 with desired phenols before manipulation of the nitro group.

A group of derivatives of $\mathbf{1}$ at the pyrone-ring other than 7a-c were prepared from 2-hydroxy-4-methanesulfonylamino-5-phenoxyacetophenone $(5, \mathrm{R}=\mathrm{H})$ as illustrated in Chart 3. The 2-methyl derivative 10a was obtained by heating $5(\mathrm{R}=\mathrm{H})$ with acetic anhydride in the presence of sodium acetate (Kostanecki-Robinson reaction) ${ }^{10}{ }^{1}$ whereas 2-ethyl compound (10b) was most conveniently prepared by a Claisen ester condensation with ethyl propionate. ${ }^{11)}$ The 2 carboxylic ester 11a was obtained by sodium hydride-mediated condensation of $5(\mathrm{R}=\mathrm{H})$ with diethyl oxalate. ${ }^{12)}$ The ester was hydrolyzed under acid conditions to give carboxylic acid $11 \mathrm{~b}$, which was converted to the carboxamide 11c via a chloride and to 2-formylamino and 2-acetoamino chromones (12a, b) using the Curtius reaction. For the preparation of 3-carboxylic ester 15a and carboxamides $16 \mathbf{a}-\mathbf{c}$, 


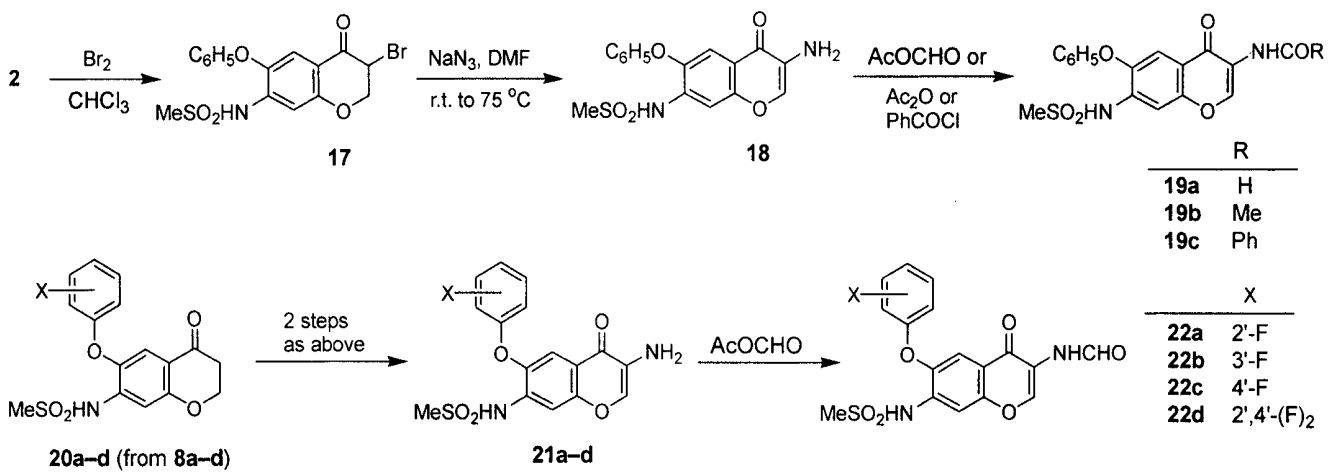

Chart 4

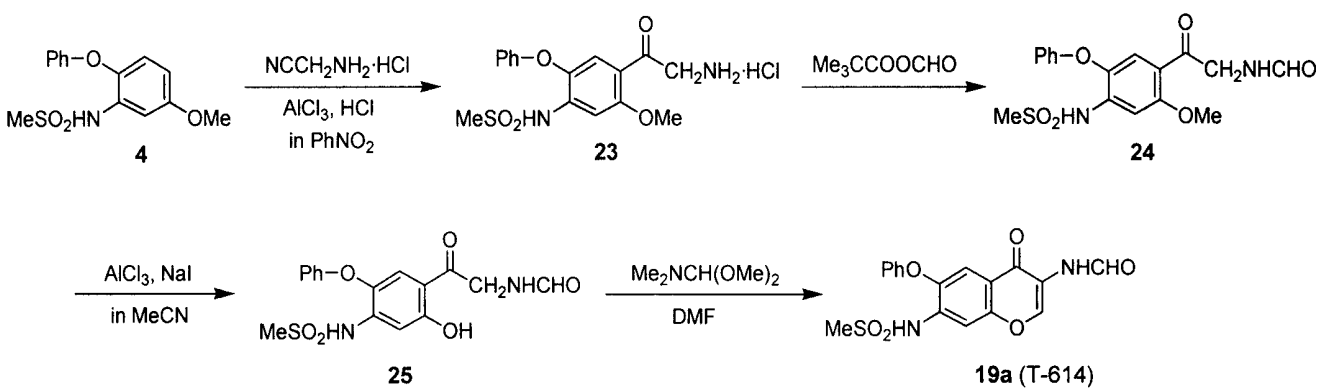

Chart 5

$O$-benzylated compound 13 was used. The 2-hydroxybenzoylacetate derivative 14 derived from 13 in two steps, which involve $\mathrm{NaH}$-mediated ethoxycarbonylation with diethyl carbonate and subsequent catalytic hydrogenolysis, was subjected to pyrone-ring annulation with $\mathrm{Me}_{2} \mathrm{NCH}(\mathrm{OMe})_{2}{ }^{13)}$ to afford 15a. It was then converted to 16a $-\mathbf{c}$ using a standard 3-step reaction: alkaline ester-hydrolysis to $\mathbf{1 5 b}$, chlorination with thionyl chloride, and amidation reaction with appropriate amines.

Chart 4 shows the synthetic route of 3-acylamino compounds $(19 \mathbf{a}-\mathbf{c}, \mathbf{2 2} \mathbf{a}-\mathbf{d})$ which utilizes a novel amination method originally reported by Szabo and Nemeth. ${ }^{14 a)}$ Typically, treatment of the 2,3-dihydrochromone 2 with bromine in chloroform afforded $\alpha$-bromo ketone 17 in $97 \%$ yield, which was allowed to react with sodium azide in DMF at $70-75^{\circ} \mathrm{C}$ for $1 \mathrm{~h}$ to give a 3-amino-chromone 18 in $80 \%$ yield. $N$-Acylation leading to $19 \mathrm{a}-\mathbf{c}$ was carried out by conventional acylation procedures. The 3 -amino precursors $\mathbf{2 1 a}-\mathbf{d}$ for the syntheses of $\mathbf{2 2} \mathbf{a}-\mathbf{d}$ (fluorine-substituted phenoxy analogues of 19a) were obtained from $\mathbf{8 a}-\mathbf{d}$ following the same procedure as employed in the preparation of 18.

After the compound 19a (T-614) was selected as a candidate for further evaluation of its pharmacological properties, we investigated an alternative, efficient synthetic route in terms of number of steps and overall yield. A four-step synthesis established is illustrated in Chart 5. Thus, the readily available starting material 4 was allowed to react with aminoacetonitrile hydrochloride in nitrobenzene in the presence of 1 equivalent of $\mathrm{AlCl}_{3}$ and excess hydrogen chloride ${ }^{15}$ ) at $25-30{ }^{\circ} \mathrm{C}$ to give an aminoacetophenone 23 in $90 \%$ yield. This material was treated with formic trimethylacetic anhydride at room temperature affording 3-formylamino compound 24 (91\% yield), which was then subjected to $O$ -
Table 1. Antiinflammatory Activity and Gastric Toxicity of Compounds 1 and 2, and Reference Drugs in Oral Administration in Rats

\begin{tabular}{|c|c|c|c|}
\hline Compound & $\begin{array}{c}\text { Carrageenin-induced } \\
\text { paw edema } \\
\mathrm{ED}_{30}(\mathrm{mg} / \mathrm{kg})\end{array}$ & $\begin{array}{l}\text { Adjuvant-induced } \\
\text { arthritis } \\
\mathrm{ED}_{40}(\mathrm{mg} / \mathrm{kg} / \mathrm{d})\end{array}$ & $\begin{array}{c}\text { Gastric toxicity }{ }^{c)} \\
\mathrm{UD}_{50}(\mathrm{mg} / \mathrm{kg})\end{array}$ \\
\hline 1 & 4.2 & 19 & $>300$ \\
\hline 2 & $>100$ & $>30$ & $>300$ \\
\hline Indomethacin & 2.0 & 0.80 & 2.2 \\
\hline Nimesulide & 2.5 & 1.6 & 170 \\
\hline Flosulide & 1.4 & 0.25 & $>300$ \\
\hline FK-3311 & 4.4 & 5.7 & $\mathrm{NT}^{d)}$ \\
\hline
\end{tabular}

a) Male Donryu rats (overnight fast) received subplantar injection of carrageenin $(1 \mathrm{mg})$ to the left hindpaw $1 \mathrm{~h}$ after oral administration of a test compound, then $3 \mathrm{~h}$ later the edema volume of each rat was measured. $b$ ) Arthritis in Lewis rats was induced by intradermal injection of heat-killed $M$. tuberculosis $(0.6 \mathrm{mg})$ in mineral oil at the tail base. A test compound was orally administered once daily from day 18 through 24 after the adjuvant injection. Volumes of both hindpaws were measured on day 25 . c) Male Wistar rats (24-h fast) received oral administration of a test compound. After another 5-h fast without water supply, the stomachs were examined for the presence of mucosal lesions to obtain the $\mathrm{UD}_{50}$ values. d) Not tested.

demethylation reaction with aluminum chloride $(2$ eq) plus sodium iodide $(1 \mathrm{eq})$ in acetonitrile solvent. ${ }^{16)}$ Reaction of the resulting product 25 with $N, N$-dimethylformamide dimethylacetal in DMF provided 19a in $67 \%$ overall yield from 4.

\section{Pharmacological Results and Discussion}

The chromone 1 and its 2,3-dihydro compound 2 were first evaluated for their antiinflammatory activity in the rat carrageenin-induced paw edema (CPE) and in the rat established adjuvant-induced arthritis (AA). The result obtained in oral administration (Table 1) shows that compound $\mathbf{1}$ is much more potent than $\mathbf{2}$ in both the acute and chronic inflammation models $\left(E_{30}=4.2 \mathrm{mg} / \mathrm{kg}\right.$ in $\mathrm{CPE} ; \mathrm{ED}_{40}=19 \mathrm{mg} / \mathrm{kg} / \mathrm{d}$ in AA). When compared the antiinflammatory efficacy of 1 
Table 2. Antiinflammatory Activity and Gastric Toxicity of Chromone Derivatives in Oral Administration in Rats

\begin{tabular}{|c|c|c|c|c|c|c|c|c|}
\hline \multirow{3}{*}{ Compd. } & \multirow{2}{*}{\multicolumn{2}{|c|}{$\begin{array}{l}\text { Carrageenin-induced } \\
\text { paw edema }\end{array}$}} & \multicolumn{4}{|c|}{ Adjuvant-induced arthritis (AA) } & \multirow{2}{*}{\multicolumn{2}{|c|}{ Gastric toxicity $^{d)}$}} \\
\hline & & & \multicolumn{2}{|c|}{ Established AA test ${ }^{b)}$} & \multicolumn{2}{|c|}{ Non-established AA test ${ }^{(c)}$} & & \\
\hline & $\begin{array}{c}\% \text { inhibition of } \\
\text { paw volume at } \\
10 \mathrm{mg} / \mathrm{kg}\end{array}$ & $\begin{array}{c}\mathrm{ED}_{30} \\
(\mathrm{mg} / \mathrm{kg})\end{array}$ & $\begin{array}{l}\% \text { reduction of } \\
\text { paw swelling at } \\
10 \mathrm{mg} / \mathrm{kg} / \mathrm{d}\end{array}$ & $\begin{array}{c}\mathrm{ED}_{40} \\
(\mathrm{mg} / \mathrm{kg} / \mathrm{d})\end{array}$ & $\begin{array}{c}\% \text { preventio } \\
\text { at } \\
0.3 \mathrm{mg} / \mathrm{kg} / \mathrm{d}\end{array}$ & $\begin{array}{c}\text { aw swelling } \\
\text { at } \\
3 \mathrm{mg} / \mathrm{kg} / \mathrm{d}\end{array}$ & $\begin{array}{c}\mathrm{UD}_{50} \\
(\mathrm{mg} / \mathrm{kg})\end{array}$ & $\begin{array}{l}\text { Lesion index } \\
\text { at } 300 \mathrm{mg} / \mathrm{kg} \\
\text { (incidence) }\end{array}$ \\
\hline $7 a$ & 33 & & 9 & & & & & \\
\hline $7 b$ & 25 & & & & & & & \\
\hline $7 c$ & 10 & & & & & & & \\
\hline $9 a$ & 46 & 3.4 & 39 & 3.1 & 7 & 56 & $>300$ & $2.9(1 / 7)$ \\
\hline $9 b$ & 32 & 12 & 25 & 18 & & & & \\
\hline $9 \mathrm{c}$ & 35 & 4.8 & 34 & 8.3 & 4 & 23 & & \\
\hline 9d & 39 & 3.4 & 36 & 2.5 & 17 & 70 & $>300$ & $2.9(1 / 7)$ \\
\hline $9 e$ & 34 & 6.0 & 37 & 4.7 & 9 & 34 & & \\
\hline 9f & 25 & 65 & 17 & 54 & & & & \\
\hline $9 \mathrm{~g}$ & 29 & & 17 & & & & & \\
\hline $9 \mathrm{~h}$ & 29 & & 15 & & & & & \\
\hline $9 \mathbf{i}$ & 16 & & 1 & & & & & \\
\hline $9 \mathrm{j}$ & 28 & & 13 & & & & & \\
\hline $10 \mathrm{a}$ & 33 & 5.0 & 30 & 6.2 & 6 & 27 & & \\
\hline $10 b$ & 14 & & -3 & & & & & \\
\hline $11 \mathrm{a}$ & 22 & & -7 & & & & & \\
\hline $11 \mathrm{~b}$ & 18 & & 6 & & & & & \\
\hline $11 \mathrm{c}$ & 19 & & 8 & & & & & \\
\hline $12 a$ & 9 & & -3 & & & & & \\
\hline $12 b$ & 12 & & -9 & & & & & \\
\hline $15 a$ & 15 & & 6 & & & & & \\
\hline $15 b$ & 21 & & 27 & & & & & \\
\hline $16 a$ & 32 & 8.3 & 36 & 12 & & & & \\
\hline $16 \mathrm{~b}$ & 27 & & 7 & & & & & \\
\hline $16 c$ & 16 & & -5 & & & & & \\
\hline $19 a$ & 40 & 3.6 & 33 & 3.6 & 44 & 57 & $>300$ & $0.7(0 / 8)$ \\
\hline $19 \mathrm{~b}$ & 17 & 80 & 9 & & & & & \\
\hline $19 \mathrm{c}$ & 14 & & 8 & & & & & \\
\hline $22 a$ & 34 & 7.2 & 38 & 3.2 & 14 & 59 & $>300$ & $6.1(3 / 8)$ \\
\hline $22 b$ & 29 & 4.5 & 25 & 10 & & & & \\
\hline $22 \mathrm{c}$ & 39 & 4.6 & 25 & 25 & & & & \\
\hline $22 d$ & 51 & 5.3 & 39 & 7.1 & 6 & 53 & $>300$ & $2.1(1 / 7)$ \\
\hline Nimesulide & & 2.5 & & 1.6 & 32 & 59 & 170 & $17.6(6 / 7)$ \\
\hline Flosulide & & 1.4 & & 0.25 & 50 & 68 & $>300$ & $8.1(3 / 7)$ \\
\hline
\end{tabular}

a) See footnote $a$ of Table 1. b) See footnote $b$ of Table 1. The reduction data were obtained on day $22 . \quad c)$ The prophylactic effects were evaluated by dosing test compounds on days 0 through $2 \mathrm{I}$ after adjuvant injection. d) See footnote $\mathrm{c}$ of Table 1. Lesion index means the sum of (1) average number of lesions, (2) average severity of lesions, and (3) \% ulcer-incidence/ 10 .

with those of some known arylsulfonamide agents shown in Table 1, the activity of 1 in preventing CPE is comparable to that of FK-3311, but 2- to 3-fold weaker than nimesulide and flosulide. With regard to therapeutic efficacy on the AA inflammation, the chromone 1 proved to be significantly less active than indomethacin as well as the sulfoanilide reference drugs. We then conducted a comparative study of gastric ulcerogenicity, which is an important adverse effect associated with classical NSAIDs in general. Compound 1 showed no indication of gastric ulceration up to $300 \mathrm{mg} / \mathrm{kg}$ in single oral administration in rats, and the $\mathrm{UD}_{50}$ value (the dose that causes gastric mucosal lesion in 50\% of animals) was evaluated to be greater than $300 \mathrm{mg} / \mathrm{kg}$. This value was of the same level as observed with flosulide but much greater than indomethacin $(2.2 \mathrm{mg} / \mathrm{kg})$ and nimesulide $(170 \mathrm{mg} / \mathrm{kg})$.

On the basis of the above comparison study, chromone 1 was selected as a lead for performing chemical modification which involves introduction of a variety of substituents at the pyrone ring as well as at the phenoxy group with the aim of enhancing the marginal activity, particularly against the es- tablished AA. First, the effect of introducing alkyl group to the pyrone ring was studied. Among the 2- and 3-alkyl derivatives, it was only 2-methyl compound (10a) that showed acceptable potency in the AA assay $\left(\mathrm{ED}_{40}=6.2 \mathrm{mg} / \mathrm{kg} / \mathrm{d}\right.$ in once daily oral administration for 7-consecutive days) and also in CPE inhibition $\left(\mathrm{ED}_{30}=5.0 \mathrm{mg} / \mathrm{kg}\right)$ as shown in Table 2 .

The effect of placing a substituent on the phenoxy ring at $\mathrm{C}(6)$ proved quite sensitive to polarity and position of the substituent. Thus, noticeable activity-enhancement against established AA was realized with those compounds having a halogen substituent at the ortho position with respect to the phenoxy oxygen as observed with $9 \mathbf{a}\left(2^{\prime}\right.$-fluoro, $\mathrm{ED}_{40}=3.1$ $\mathrm{mg} / \mathrm{kg}), 9 d\left(2^{\prime}, 4^{\prime}\right.$-difluoro, $\left.\mathrm{ED}_{40}=2.5 \mathrm{mg} / \mathrm{kg}\right)$, and 9e $\left(2^{\prime}\right.$ chloro, $\mathrm{ED}_{40}=4.7 \mathrm{mg} / \mathrm{kg}$ ). The $4^{\prime}$-fluorophenoxy compound 9c was about 2.5-fold less potent than 9a ( $2^{\prime}$-fluorophenoxy) but roughly equipotent to $\mathbf{1 0 a}$ in $\mathrm{CPE}$ inhibition. Furthermore, the 3'-fluorophenoxy and 4'-chlorophenoxy compounds $(\mathbf{9 b}, 9 \mathbf{9})$ were considerably less active showing $\mathrm{ED}_{40}$ values of 18 and $54 \mathrm{mg} / \mathrm{kg}$ in the AA assay, respectively, although they were more potent than the methyl and methoxy 
derivatives $9 \mathbf{g}-\mathbf{j}$.

We next turned to the evaluation of compounds bearing an amide functionality, which is attached at the pyrone ring in the constitutionally isomeric form of (chromon-2 or 3-yl)carboxamide or ( 2 or 3 -acylamino) chromone. Of the carboxamide compounds $(11 \mathrm{c}, 16 \mathbf{a}-\mathbf{c})$, the primary 3 -carboxamide 16a was most potent but unacceptable in terms of its $\mathrm{ED}_{40}$ $(\mathrm{AA})=12 \mathrm{mg} / \mathrm{kg}$ and $\mathrm{ED}_{30}(\mathrm{CPE})=8.3 \mathrm{mg} / \mathrm{kg}$. Among the acylamino compounds $(\mathbf{1 2 a}, \mathbf{b}$ and $19 \mathbf{a}-\mathbf{c})$, on the other hand, we found the 3 -formylaminochromone 19a displaying remarkable potency, $\mathrm{ED}_{40}(\mathrm{AA})=3.6 \mathrm{mg} / \mathrm{kg}$ and $\mathrm{ED}_{30}$ $(\mathrm{CPE})=3.6 \mathrm{mg} / \mathrm{kg}$, the values being comparable to those obtained with 9a (2'-fluoro) and 9d (2', $4^{\prime}$-difluoro).

Encouraged by finding the potential 3-formylamino compound 19a, we synthesized its mono and difluoro derivatives at the phenoxy ring $(\mathbf{2 2 a}-\mathbf{d})$. In accordance with the structure-activity relationship previously obtained with the corresponding $3(\mathrm{H})$ samples $(\mathbf{9 a}-\mathbf{d})$, compounds 22a $\left(2^{\prime}\right.$-fluoro/3-formylamino) and $\mathbf{2 2 d}\left(2^{\prime}, 4^{\prime}\right.$-difluoro/3-formylamino) showed good AA-therapeutic activity but remained at the levels roughly comparable to the fluorine-free molecule 19a.

We then conducted defining prophylactic anti-AA potency of the eight compounds $(9 \mathbf{a}, \mathbf{c}-\mathbf{e} ; 10 \mathrm{10} ; 19 \mathrm{a} ; 2 \mathrm{22} \mathbf{a}, \mathbf{d})$ which were selected for their good CPE-inhibition $\left(\mathrm{ED}_{30}\right.$ values of $3.4-7.2 \mathrm{mg} / \mathrm{kg}$ ) as well as noticeable therapeutic activity against the established $\mathrm{AA}\left(\mathrm{ED}_{40}\right.$ values of $\left.2.5-8.3 \mathrm{mg} / \mathrm{kg}\right)$. The assessment with Lewis rats was carried out by once daily oral administration of test compounds $(0.3$ and $3.0 \mathrm{mg} / \mathrm{kg}$ ) for 22-consecutive days beginning on the day of the adjuvant injection. The prophylactic activities (Table 2), which are roughly equipotent to nimesulide and flosulide, were obtained with 9a, 9d, 19a, 22a and 22d (suppression ranging from 53 to $70 \%$ at $3.0 \mathrm{mg} / \mathrm{kg}$ ).

At this stage of the selection of the five compounds (Chart 6 ), they were evaluated for their potential gastric toxicity in fasted rats in terms of the $\mathrm{UD}_{50}$ value and the lesion index $(\Sigma$ average number of lesions + average severity of lesions $+\%$ incidence $\times 0.1),{ }^{17)}$ which were determined $5 \mathrm{~h}$ after oral administration of each compound. The data shown in Table 2 indicate that all of the five compounds display low ulcerogenic liability with the acute $\mathrm{UD}_{50}$ values of $>300 \mathrm{mg} / \mathrm{kg}$, significantly less toxic than nimesulide $\left(\mathrm{UD}_{50}=170 \mathrm{mg} / \mathrm{kg}\right)$, and that the fluorine-free compound 19a has the best safety profile as seen by its smallest lesion index $(0.7$ at 300 $\mathrm{mg} / \mathrm{kg}$ ), which was smaller than that of flosulide (8.1).

On the basis of its overall pharmacological profile described above, compound 19a was selected for further inves- tigations focusing on its antiarthritic potential. Accordingly, we tested the effect of 19a on collagen-induced arthritis (CIA) in DBA/1J mice using a progression-preventive dosing regimen, in which once daily oral administration of the test compound was initiated on day 21 shortly after the secondary immunization with a mixture of bovine type II collagen and Freund's complete adjuvant (FCA). Compound 19a effectively reduced progression of paw-swelling, suppression of $38 \%$ at $30 \mathrm{mg} / \mathrm{kg}$ and $57 \%$ at $100 \mathrm{mg} / \mathrm{kg}$ after 2 weeks (Table 3 ). Evidence for the beneficial effect against joint degeneration was obtained by an X-ray radiographic analysis of the joints, which was carried out after termination of the pawswelling evaluation. The inhibition $\%$ data derived from severity scores (Table 3 ) indicate that compound $19 a$ ( $89 \%$ at $30 \mathrm{mg} / \mathrm{kg}$ ) is significantly more potent than nimesulide and flosulide. To understand the remarkable anti-CIA potency of 19a, we measured serum levels of interleukin-6 (IL-6) in dosing 19a and nimesulide, since enhanced production of the cytokine in CIA mice has been reported. ${ }^{18)}$ Concentrations of IL-6 were determined by an enzyme-linked immunosorbent assay (ELISA) using blood samples from animals receiving administration of a test compound from day 0 through day 34 $(30 \mathrm{mg} / \mathrm{kg} / \mathrm{d})$. In the mice treated with $19 \mathrm{a}$, there was observed an $88 \%$ reduction of IL- 6 level, whereas nimesulide gave much smaller reduction of $26 \%$.

In conclusion, chemical modification of compound $\mathbf{1}$, which involves introduction of a variety of substituents at the phenoxy and pyrone groups, has provided us with compound 19a (designated T-614) which demonstrates potent antiarthritic activity in chronic inflammatory disease models. It is a member of the methanesulfoanilide agents as represented
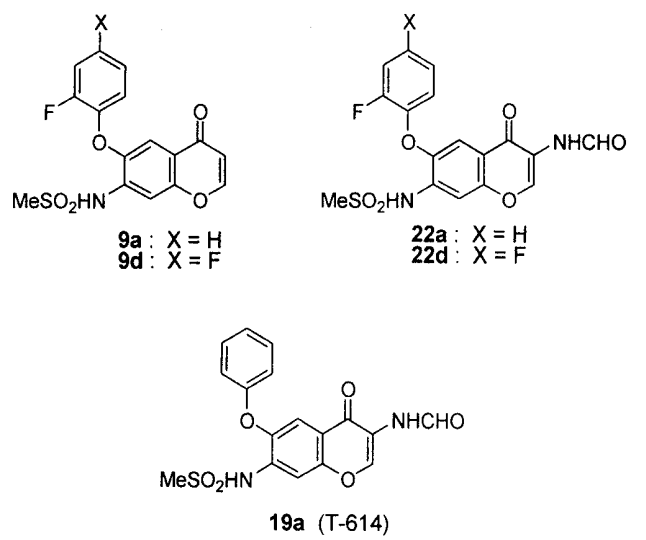

Chart 6

Table 3. Effect on type II Collagen-induced Arthritis in Male DBA/1 J Mice

\begin{tabular}{|c|c|c|c|c|c|}
\hline \multirow{2}{*}{ Compound } & \multirow{2}{*}{$\begin{array}{c}\text { Dose } \\
(\mathrm{mg} / \mathrm{kg} / \mathrm{d})\end{array}$} & \multicolumn{2}{|c|}{ Paw-swelling ${ }^{a)}$} & \multicolumn{2}{|c|}{ Joint-degeneration $^{b)}$} \\
\hline & & Arthritis score ${ }^{c)}$ & $\%$ inhibition $^{d)}$ & Severity score ${ }^{c)}$ & $\%$ inhibition $^{d)}$ \\
\hline Control & - & $6.9 \pm 0.7$ & - & $15.5 \pm 3.1$ & - \\
\hline \multirow[t]{2}{*}{ 19a (T-614) } & 30 & $4.3 \pm 0.6$ & 38 & $1.6 \pm 0.6$ & $89 *$ \\
\hline & 100 & $3.0 \pm 1.2$ & $57^{*}$ & $1.9 \pm 1.8$ & $88^{*}$ \\
\hline Nimesulide & 30 & $6.0 \pm 1.2$ & 13 & $14.3 \pm 3.6$ & 8 \\
\hline Flosulide & 30 & $5.4 \pm 1.5$ & 22 & $12.6 \pm 3.9$ & 19 \\
\hline
\end{tabular}

a) Arthritis in mice was induced by injection of a mixture of bovine type II collagen and FCA on days 0 and 21 . Test compounds were orally administered once daily starting on day 21 and over the period of 2 weeks. $b$ ) The paws were removed on day 35 for counting the number of degenerated joints by an X-ray radiographic analysis as described in the experimental section. c) The scoring system is described in the experimental section, and the data are expressed as mean \pm S.E. $(n=7)$. $d) *, p<0.05$ as compared with the control by non-parametric Dunnett test. 
Table 4. Characterization Data of N-(5-Methoxy-2-phenoxyphenyl)methanesulfonamides

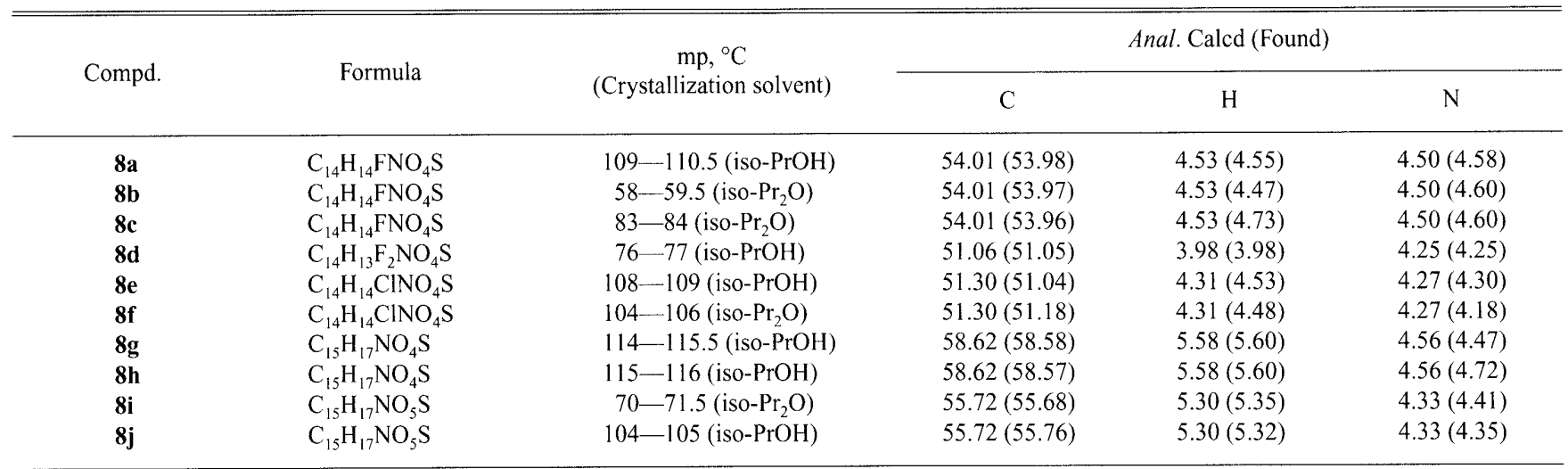

Table 5. Characterization Data of $N$-(4-Oxo-6-phenoxy-4H-7-chromenyl)methanesulfonamide Derivatives

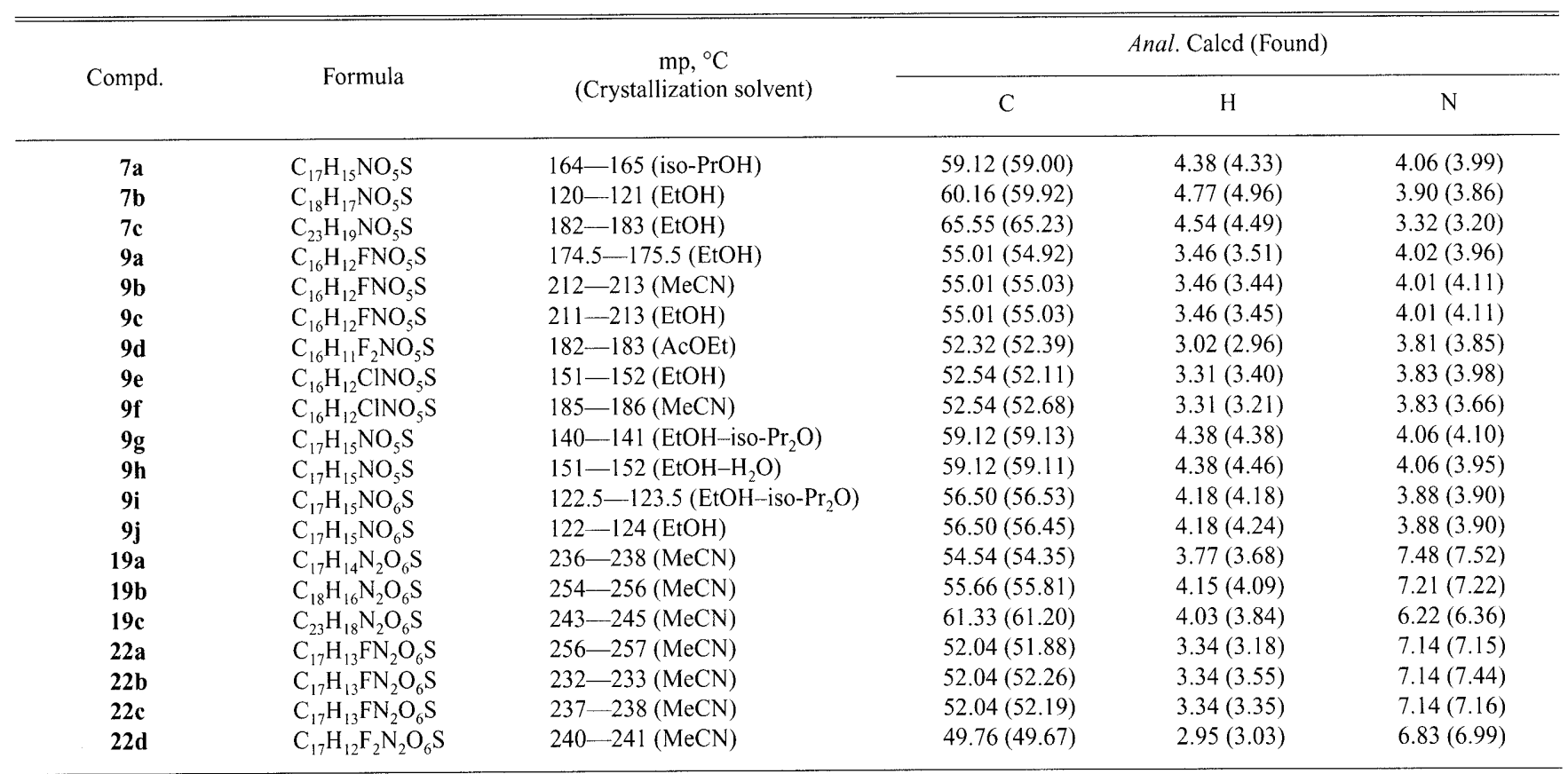

by nimesulide and flosulide (Chart 1) but has structural features of a chromone core-framework and two chemically different amide groups, formamide and methanesulfonamide functionalities at the remote 3- and 7-positions, respectively. Important pharmacological profiles of T-614 reported in this paper are (1) its low gastro-ulcerogenic liability in oral administration ${ }^{19,20)}$ and (2) its notable activity against progressive joint destruction in mice CIA models, the potency being significantly greater than nimesulide and flosulide. Clinical evaluations of T-614 as a slow-acting (disease-modifying) antirheumatic agent ${ }^{21)}$ are in progress.

\section{Experimental}

Chemistry Melting points were determined using a Büchi 535 melting point apparatus and are uncorrected. Combustion elemental analysis $(\mathrm{C}, \mathrm{H}$, N) was carried out at the analytical department of Toyama Chemical Company, Ltd., using a Yanako MT-3 instrument. 'H-NMR spectra were recorded on a JEOL FX 60 or LA 400 spectrometer with TMS as an internal standard. Infrared spectra were obtained with a Hitachi 260-30 spectrometer. Column chromatography was performed using Merck Silica gel 60 ( 70 -230 mesh).

$\mathrm{N}$-(5-Methoxy-2-phenoxyphenyl)methanesulfonamide (4) and Its Substituted 2-Phenoxy Analogues (8a-j) Potassium tert-butoxide (13.5 g, $0.12 \mathrm{~mol})$ was added to a stirred solution of phenol $(11.3 \mathrm{~g}, 0.12 \mathrm{~mol})$ and $4-$ chloro-3-nitroanisole (3) $(18.8 \mathrm{~g}, 0.10 \mathrm{~mol})$ in dry DMF $(100 \mathrm{ml})$, and the mixture was heated at $110^{\circ} \mathrm{C}$ for $4 \mathrm{~h}$ before pouring into ice-water. The whole was extracted with AcOEt, and the organic phase was sequentially washed with $2 \mathrm{~N} \mathrm{HCl}$ and water, dried on $\mathrm{MgSO}_{4}$, and concentrated. The residue was purified by silica gel chromatography (hexane-toluene $=3: 1$ ) to give 3-nitro-4-phenoxyanisole $(20.6 \mathrm{~g}, 84 \%)$, mp $37.5-38.5^{\circ} \mathrm{C}$ after recrystallization from iso- $\mathrm{Pr}_{2} \mathrm{O}$-hexane. Anal. Calcd for $\mathrm{C}_{13} \mathrm{H}_{11} \mathrm{NO}_{4}: \mathrm{C}, 63.67 ; \mathrm{H}$, 4.52 ; N, 5.71. Found: $\mathrm{C}, 63.81 ; \mathrm{H}, 4.50 ; \mathrm{N}, 5.51$. The nitro compound obtained here $(20.0 \mathrm{~g}, 79 \mathrm{mmol})$ was dissolved in a mixture of $50 \% \mathrm{EtOH}$ $(200 \mathrm{ml})$ and $4 \mathrm{~N} \mathrm{HCl}(5 \mathrm{ml})$, and to the solution was added iron powder $(13.7 \mathrm{~g})$ portionwise over $20 \mathrm{~min}$ at $65-70^{\circ} \mathrm{C}$. After continued stirring at the same temperature for $30 \mathrm{~min}$, the reaction mixture was filtered and the filtrate was diluted with water to precipitate the reduction product. It was purified by recrystallization from toluene to afford 3-amino-4-phenoxyanisole $(12.6 \mathrm{~g}, 72 \%)$, mp $112-112.5^{\circ} \mathrm{C}$. Anal. Calcd for $\mathrm{C}_{13} \mathrm{H}_{13} \mathrm{NO}_{2}: \mathrm{C}, 72.54 ; \mathrm{H}$, 6.09 ; N, 6.51. Found: C, 72.59; H, 5.99; N, 6.45 .

The amino compound $(10.0 \mathrm{~g}, 46 \mathrm{mmol})$ was dissolved in dry pyridine $(50 \mathrm{ml})$, and the solution was cooled to $0-5^{\circ} \mathrm{C}$ and treated with $\mathrm{MeSO}_{2} \mathrm{Cl}$ $(5.6 \mathrm{~g}, 49 \mathrm{mmol})$. After being stirred at room temperature for $1 \mathrm{~h}$, the reaction mixture was poured into water, and the whole was extracted with AcOEt. The organic phase was successively washed with $2 \mathrm{~N} \mathrm{HCl}$ and water, dried on $\mathrm{MgSO}_{4}$, and concentrated under reduced pressure. The residue was crystallized from EtOH to give $4(11.1 \mathrm{~g}, 82 \%)$, mp $109.5-111^{\circ} \mathrm{C}$. Anal. Calcd for $\mathrm{C}_{14} \mathrm{H}_{15} \mathrm{NO}_{4} \mathrm{~S}: \mathrm{C}, 57.32 ; \mathrm{H}, 5.15 ; \mathrm{N}, 4.78$. Found: C, $57.21 ; \mathrm{H}, 5.04$; $\mathrm{N}, 4.79$.

The analogues $8 \mathbf{a}-\mathbf{j}$ having halo, methyl and methoxy substituents at the 2-phenoxy group were also prepared from 3 by subjecting them to the same sequence of reactions, except that reduction of the nitro group was performed by $\mathrm{Pd}-\mathrm{C}$ catalyzed hydrogenation. Their characterization data are 
given in Table 4

$\mathrm{N}$-(4-Ox0-6-phenoxy-4H-7-chromenyl)methanesulfonamide (1) (General Procedure for the Synthesis of $7 \mathbf{a}-\mathbf{c}$ and $9 \mathrm{a}-\mathrm{j})$ Aluminum chloride $(26.5 \mathrm{~g}, 0.20 \mathrm{~mol})$ was added to a stirred and cooled $\left(0-5^{\circ} \mathrm{C}\right)$ solution of $4(29.3 \mathrm{~g}, 0.10 \mathrm{~mol})$ and acetyl chloride $(7.7 \mathrm{~g}, 98 \mathrm{mmol})$ in dry $\mathrm{CH}_{2} \mathrm{Cl}_{2}$ $(300 \mathrm{ml})$. After being stirred at $15-20^{\circ} \mathrm{C}$ for $1 \mathrm{~h}$, the mixture was poured onto ice-water and phases were separated. The organic layer was washed with water, dried on $\mathrm{MgSO}_{4}$, and concentrated. The solid residue was crystallized from 2-propanol to give $5(\mathrm{R}=\mathrm{H})(27.0 \mathrm{~g}, 84 \%), \mathrm{mp} 153-155^{\circ} \mathrm{C}$, IR (KBr) 3240, $1625 \mathrm{~cm}^{-1}$. Anal. Calcd for $\mathrm{C}_{15} \mathrm{H}_{15} \mathrm{NO}_{5} \mathrm{~S}: \mathrm{C}, 56.07 ; \mathrm{H}, 4.71$; $\mathrm{N}, 4.36$. Found: C, 56.07; H, 4.63; N, 4.46.

A stirred suspension of $5(\mathrm{R}=\mathrm{H})(5.0 \mathrm{~g}, 15.6 \mathrm{mmol})$ in triethyl orthoformate $(50 \mathrm{ml})$ was treated with $70 \% \mathrm{HClO}_{4}(4.5 \mathrm{~g})$ at room temperature. After $1 \mathrm{~h}$, crystalline precipitate of a benzopyrylium salt $(6)(\mathrm{R}=\mathrm{H})$ was filtered and washed with ether. This material was treated with boiling water $(50 \mathrm{ml})$ for $5 \mathrm{~min}$ to give $1(4.4 \mathrm{~g}, 85 \%)$ after recrystallization from $\mathrm{MeCN}, \mathrm{mp}$ $217-218^{\circ} \mathrm{C}$, IR $(\mathrm{KBr}) 3240,1625 \mathrm{~cm}^{-1}$. Anal. Calcd for $\mathrm{C}_{16} \mathrm{H}_{13} \mathrm{NO}_{5} \mathrm{~S}: \mathrm{C}$, $58.00 ; \mathrm{H}, 3.95 ; \mathrm{N}, 4.23$. Found: C, 57.94; H, 3.88; N, 4.05 .

Compounds $7 \mathbf{a}-\mathbf{c}$ (3-alkyl derivatives of 1 ) were prepared from 4 by the same 2 -step procedure in which appropriate $\alpha$-substituted acetyl chlorides were used in the Friedel-Crafts acylation step. Compounds $9 \mathbf{a}-\mathbf{j}$ were prepared from $\mathbf{8 a}-\mathbf{j}$ utilizing the same 2-step procedure as described for the transformation of $\mathbf{4}$ to $\mathbf{1}$. The characterization data for $7 \mathbf{a}-\mathbf{c}$ and $9 \mathbf{a}-\mathbf{j}$ are given in Table 5 .

$N$-(4-Oxo-6-phenoxy-2,3-dihydro-4H-7-chromenyl)methanesulfonamide (2) and Its Phenoxy-Substituted Compounds (20a-d) A solution of $1(10.0 \mathrm{~g}, 30 \mathrm{mmol})$ in $\mathrm{AcOH}(200 \mathrm{ml})$ was stirred at $40-45^{\circ} \mathrm{C}$ under an atmospheric pressure of $\mathrm{H}_{2}$ in the presence of $5 \% \mathrm{Pd}-\mathrm{C}$ and for $1 \mathrm{~h}$. The hydrogenation product 2 was obtained by filtration of the catalyst and evaporation of the solvent, $\mathrm{mp} 143-144^{\circ} \mathrm{C}$ after recrystallization from MeOH. Anal. Calcd for $\mathrm{C}_{16} \mathrm{H}_{15} \mathrm{NO}_{5} \mathrm{~S}: \mathrm{C}, 57.65 ; \mathrm{H}, 4.54 ; \mathrm{N} ; 4.20$. Found: $\mathrm{C}$, $57.60 ; \mathrm{H}, 4.43 ; \mathrm{N}, 4.21$. Using the same catalytic hydrogenation procedure, the following fluoro derivatives $\mathbf{2 0 a}-\mathbf{d}$ were prepared from $\mathbf{8 a}-\mathbf{d}$.

$\mathrm{N}$-[4-Oxo-6-(2-fluorophenoxy)-2,3-dihydro-4H-7-chromenyl]methanesulfonamide (20a): $\mathrm{mp} 131-132{ }^{\circ} \mathrm{C}$ from $\mathrm{EtOH}$ (70\% yield). Anal. Calcd for $\mathrm{C}_{16} \mathrm{H}_{14} \mathrm{FNO}_{5} \mathrm{~S}: \mathrm{C}, 54.70 ; \mathrm{H}, 4.02 ; \mathrm{N}, 3.99$. Found: C, 54.69; H, 4.02; N, 3.93.

$\mathrm{N}$-[4-Oxo-6-(3-fluorophenoxy)-2,3-dihydro-4H-7-chromenyl]methanesulfonamide (20b): $\mathrm{mp} 146-147^{\circ} \mathrm{C}$ from $\mathrm{EtOH}$ (68\% yield). Anal. Calcd for $\mathrm{C}_{16} \mathrm{H}_{14} \mathrm{FNO}_{5} \mathrm{~S}: \mathrm{C}, 54.70 ; \mathrm{H}, 4.02 ; \mathrm{N}, 3.99$. Found: C, 54.88; H, 4.04; N, 4.14

$\mathrm{N}$-[4-Oxo-6-(4-fluorophenoxy)-2,3-dihydro-4H-7-chromenyl]methanesulfonamide (20c): $\mathrm{mp} 167-168^{\circ} \mathrm{C}$ from $\mathrm{EtOH}$ (74\% yield). Anal. Calcd for $\mathrm{C}_{16} \mathrm{H}_{14} \mathrm{FNO}_{5} \mathrm{~S}: \mathrm{C}, 54.70 ; \mathrm{H}, 4.02 ; \mathrm{N}, 3.99$. Found: $\mathrm{C}, 54.91 ; \mathrm{H}, 4.08 ; \mathrm{N}, 3.86$.

$\mathrm{N}$-[4-Oxo-6-(2,4-difluorophenoxy)-2,3-dihydro-4H-7-chromenyl]methanesulfonamide (20d): $\mathrm{mp} 163.5-165^{\circ} \mathrm{C}$ from EtOH ( $86 \%$ yield). Anal. Calcd for $\mathrm{C}_{16} \mathrm{H}_{13} \mathrm{~F}_{2} \mathrm{NO}_{5} \mathrm{~S}$ : C, 52.03; H, 3.55; N, 3.79. Found: C, 51.94; H, 3.51; N, 3.91

$\mathrm{N}$-(4-Oxo-2-methyl-6-phenoxy-4H-7-chromenyl)methanesulfonamide (10a) A mixture of $5(\mathrm{R}=\mathrm{H})(3.21 \mathrm{~g}), \mathrm{Ac}_{2} \mathrm{O}(5.45 \mathrm{~g})$, and $\mathrm{AcONa}(4.1 \mathrm{~g})$ was stirred and heated at $130-140^{\circ} \mathrm{C}$ for $1.5 \mathrm{~h}$. The mixture was then cooled to room temperature and AcOEt $(200 \mathrm{ml})$ and water $(100 \mathrm{ml})$ were added. The organic layer was separated, washed with water and brine, dried on $\mathrm{MgSO}_{4}$, and concentrated. The solid residue was crystallized from AcOEt to give $10 \mathrm{a}(0.86 \mathrm{~g}, 25 \%)$, mp $186.5-187^{\circ} \mathrm{C}$. Anal. Calcd for $\mathrm{C}_{17} \mathrm{H}_{15} \mathrm{NO}_{5} \mathrm{~S}$ : C, 59.12; H, 4.38; N, 4.06. Found: C, 59.27; H, 4.41; N, 4.11.

$\mathrm{N}$-(4-Oxo-2-ethyl-6-phenoxy-4H-7-chromenyl)methanesulfonamide (10b) Sodium hydride ( $60 \%$ dispersion in mineral oil, $0.93 \mathrm{~g}$ ) was added to a stirred suspension of $5(\mathrm{R}=\mathrm{H})(1.5 \mathrm{~g}, 4.67 \mathrm{mmol})$ and ethyl propanoate $(25 \mathrm{ml})$, and the mixture was heated under reflux for $2 \mathrm{~h}$ before pouring into ice-water. The whole was extracted with AcOEt after adjusting its $\mathrm{pH}$ at 5 with $4 \mathrm{~N} \mathrm{HCl}$. The organic phase was concentrated, and the residue was dissolved in a mixture of $12 \mathrm{~N} \mathrm{HCl}(2.0 \mathrm{ml})$ and acetic acid $(18 \mathrm{ml})$ before heating at $70-80^{\circ} \mathrm{C}$ for $30 \mathrm{~min}$. The mixture was then cooled to room temperature and extracted with AcOEt. The extract was washed with water, dried, and concentrated. The residual solid was crystallized from 2-propanol to give 10b $(1.3 \mathrm{~g}, 78 \%)$, mp $187.5-188.5^{\circ} \mathrm{C}$. Anal. Calcd for $\mathrm{C}_{18} \mathrm{H}_{17} \mathrm{NO}_{5} \mathrm{~S}$ : C, 60.16; C, 4.77; N, 3.90. Found: C, 60.20; H, 4.70; N, 3.90.

7-I(Methylsulfonyl)aminol-4-oxo-6-phenoxy-4H-2-chromenecarboxylic Acid (11b) Sodium hydride (60\% dispersion in mineral oil, $3.1 \mathrm{~g}$ ) was added to a stirred suspension of $5(R=H)(5.0 \mathrm{~g}, 15.6 \mathrm{mmol})$ and diethyl oxalate $(4.9 \mathrm{~g}, 33.5 \mathrm{mmol})$ in dry $\mathrm{EtOH}(85 \mathrm{ml})$, and the mixture was heated under reflux for $1.5 \mathrm{~h}$ before pouring into ice-water. The whole was extracted with AcOEt after acidification to $\mathrm{pH} 2$ with $4 \mathrm{~N} \mathrm{HCl}$ followed by filtration of the crystalline precipitate. This material was dissolved in a mixture of $12 \mathrm{~N} \mathrm{HCl}(1.0 \mathrm{ml})$ and $\mathrm{AcOH}(50 \mathrm{ml})$, and the solution was heated at $80^{\circ} \mathrm{C}$ for $10 \mathrm{~min}$ before cooling and extraction with AcOEt. The organic phase was washed with water, dried, and concentrated. The residue was crystallized from a mixture of 2-propanol and AcOEt to afford 11a (ethyl ester of 11b) $(3.5 \mathrm{~g}, 56 \%), \mathrm{mp} 155-156^{\circ} \mathrm{C}$. Anal. Calcd for $\mathrm{C}_{19} \mathrm{H}_{17} \mathrm{NO}_{7} \mathrm{~S}: \mathrm{C}, 56.57$; $\mathrm{H}, 4.25$; N, 3.47. Found: C, 56.44; H, 4.21; N, 3.51

A suspension of $11 \mathrm{a}(3.5 \mathrm{~g}, 8.7 \mathrm{mmol})$ in $\mathrm{AcOH}(30 \mathrm{ml})$ and $12 \mathrm{~N} \mathrm{HCl}$ $(20 \mathrm{ml})$ was heated under reflux for $1 \mathrm{~h}$. The reaction mixture was diluted with water to precipitate the product, which was crystallized from $\mathrm{AcOH}$ to give $11 \mathrm{~b}(3.0 \mathrm{~g}, 92 \%), \mathrm{mp} 256-258^{\circ} \mathrm{C}$. Anal. Calcd for $\mathrm{C}_{17} \mathrm{H}_{13} \mathrm{NO}_{7} \mathrm{~S}: \mathrm{C}$, $54.40 ; \mathrm{H}, 3.49$; N, 3.73. Found: C, 54.44; H, 3.71; N, 3.85 .

7-[(Methylsulfonyl)amino]-4-0xo-6-phenoxy-4H-2-chromenecarboxamide (11c) Thionyl chloride $(3.8 \mathrm{~g})$ and DMF $(0.1 \mathrm{ml})$ was added to a stirred suspension of $11 \mathrm{~b}(3.0 \mathrm{~g}, 8.0 \mathrm{mmol})$ in $\mathrm{CH}_{2} \mathrm{Cl}_{2}(30 \mathrm{ml})$, and the mixture was heated under reflux for $1.5 \mathrm{~h}$ before concentration under reduced pressure. The residual chloride $(3.1 \mathrm{~g})$, IR (neat) $1760 \mathrm{~cm}^{-1}$, was poured into an excess amount of ice-cooled $25 \% \mathrm{NH}_{4} \mathrm{OH}$ solution, and the whole was stirred at room temperature for $30 \mathrm{~min}$. The whole was acidified to $\mathrm{pH} 2$ with $4 \mathrm{~N} \mathrm{HCl}$, and extracted with AcOEt. The organic extract was washed with water, dried, and concentrated. The residue was crystallized from $\mathrm{MeOH}$ to give $11 \mathrm{c}(0.60 \mathrm{~g}, 20 \%), \mathrm{mp}>280^{\circ} \mathrm{C}$. Anal. Calcd for $\mathrm{C}_{17} \mathrm{H}_{14} \mathrm{~N}_{2} \mathrm{O}_{6} \mathrm{~S}: \mathrm{C}, 54.54 ; \mathrm{H}, 3.77 ; \mathrm{N}, 7.48$. Found: C, 54.66; H, 3.68; N, 7.35 .

2-Formylamino and 2-Acetoamino Derivatives of 1 (12a and 12b) A solution of the chloride of $11 \mathbf{b}$ ( $3.1 \mathrm{~g}$, obtained in the above section) in tetrahydrofuran (THF) $(80 \mathrm{ml})$ was added over $10 \mathrm{~min}$ to a stirred solution of sodium azide $(1.26 \mathrm{~g}, 19 \mathrm{mmol})$ in water $(10 \mathrm{ml})$ at $5-10^{\circ} \mathrm{C}$. After being stirred at the same temperature for $1.5 \mathrm{~h}$, the reaction mixture was filtered to obtain the deposited azide product, which was dried over $\mathrm{P}_{2} \mathrm{O}_{5}$ under reduced pressure, $1.45 \mathrm{~g},(46 \%)$, IR $(\mathrm{KBr}) 2115 \mathrm{~cm}^{-1}$. A portion of the azide $(1.0 \mathrm{~g}, 2.5 \mathrm{mmol})$ in $\mathrm{MeCN}(10 \mathrm{ml})$ containing formic acid $(0.17 \mathrm{~g}, 3.7$ $\mathrm{mmol}$ ) was heated under reflux for $1.5 \mathrm{~h}$. The mixture was cooled and filtered to remove insoluble material, and the filtrate was concentrated under reduced pressure. The residue was subjected to silica gel chromatography (toluene-AcOEt $=1: 1$ ), followed by crystallization of the homogeneous product from $\mathrm{MeCN}$ to give $12 \mathrm{a}(0.27 \mathrm{~g}, 29 \%), \mathrm{mp} 214-216^{\circ} \mathrm{C}$. Anal. Calcd for $\mathrm{C}_{17} \mathrm{H}_{14} \mathrm{~N}_{2} \mathrm{O}_{6} \mathrm{~S}$ : C, 54.54; $\mathrm{H}, 3.77 ; \mathrm{N}, 7.48$. Found: $\mathrm{C}, 54.70 ; \mathrm{H}$, $3.78 ; \mathrm{N}, 7.55$.

The $N$-acetyl compound $\mathbf{1 2 b}$ was obtained by decomposing the azide intermediate in the presence of $\mathrm{AcOH}(1.5 \mathrm{eq}), \mathrm{mp} 236-238^{\circ} \mathrm{C}$ after recrystallization from EtOH (31\% yield). Anal. Calcd for $\mathrm{C}_{18} \mathrm{H}_{16} \mathrm{~N}_{2} \mathrm{O}_{6} \mathrm{~S}$ : C, 55.66 H, 4.15; N, 7.21. Found: C, 55.81; H, 3.88; N, 6.95 .

Ethyl 3-\{2-Hydroxy-4-|(methylsulfonyl)amino|-5-phenoxyphenyl\}-3-0xopropanoate (14) $O$-Benzylation of $5(\mathrm{R}=\mathrm{H})$ with benzyl bromide in the presence of $\mathrm{NaH}$ in $\mathrm{DMF}$ was carried out according to a standard procedure to give 13 in $50 \%$ yield, mp $132-134{ }^{\circ} \mathrm{C}$ from toluene. Anal. Calcd for $\mathrm{C}_{22} \mathrm{H}_{21} \mathrm{NO}_{5} \mathrm{~S}$ : C, 64.22; H, 5.14; N, 3.40. Found: C, 63.84; H, 5.16; N, 3.67.

Sodium hydride $(60 \%$ dispersion in mineral oil, $1.6 \mathrm{~g}$ ) was added to a stirred solution of $13(4.11 \mathrm{~g}, 9.96 \mathrm{mmol})$ in diethyl carbonate $(20 \mathrm{ml})$ and DMF $(20 \mathrm{ml})$. After being heated at $90-100^{\circ} \mathrm{C}$ for $30 \mathrm{~min}$, the reaction mixture was cooled and poured into ice-water. The aqueous phase was separated and washed with ether, then extracted with AcOEt at $\mathrm{pH} 5$ adjusted with $4 \mathrm{~N} \mathrm{HCl}$. The organic extract was washed with water, dried on $\mathrm{MgSO}_{4}$ and concentrated. The residue was purified by silica gel chromatography (toluene-AcOEt $=3: 1$ ), followed by crystallization from iso- $\mathrm{Pr}_{2} \mathrm{O}$ to give $O$ benzyl ether of $14(3.2 \mathrm{~g}, 66 \%), \mathrm{mp} 85-90^{\circ} \mathrm{C}$. Anal. Calcd for $\mathrm{C}_{25} \mathrm{H}_{25} \mathrm{NO}_{7} \mathrm{~S}$ : C, 62.10; H, 5.21; N, 2.90. Found: C, 62.38; H, 5.36; N, 2.69. This material was subjected to $5 \% \mathrm{Pd}-\mathrm{C}$ catalyzed hydrogenolysis in $\mathrm{EtOH}$ to afford 14 in $90 \%$ yield, $\mathrm{mp} 111.5-112.5^{\circ} \mathrm{C}$ after recrystallization from a mixture of 2-propanol and AcOEt. Anal. Calcd for $\mathrm{C}_{18} \mathrm{H}_{19} \mathrm{NO}_{7} \mathrm{~S}: \mathrm{C}, 54.95$; $\mathrm{H}, 4.87$; N, 3.56. Found: C, 55.12; H,4.85; N, 3.16 .

Ethyl 7-[(Methylsulfonyl)amino]-4-oxo-6-phenoxy-4H-3-chromenecarboxylate (15a) A solution of $14(3.9 \mathrm{~g}, 10 \mathrm{mmol})$ in DMF $(40 \mathrm{ml})$ was treated with $\mathrm{Me}_{2} \mathrm{NCH}(\mathrm{OMe})_{2}(2.6 \mathrm{~g}, 22 \mathrm{mmol})$ at room temperature for $1 \mathrm{~h}$ before pouring into water. The whole was extracted with AcOEt after acidification with $4 \mathrm{~N} \mathrm{HCl}$. The organic phase was washed with water, dried, and concentrated under reduced pressure. The residue was crystallized from $\mathrm{EtOH}$ to give $15 \mathrm{a}(3.6 \mathrm{~g}, 89 \%)$, mp $167-168^{\circ} \mathrm{C}$. Anal. Calcd for $\mathrm{C}_{19} \mathrm{H}_{17} \mathrm{NO}_{7} \mathrm{~S}$ : C, 56.57; H, 4.25; N, 3.47. Found: C, 56.54; H, 4.49; N, 3.20 . A mixture of the ester $15 \mathrm{a}(2.0 \mathrm{~g}, 5 \mathrm{mmol})$, dioxane $(40 \mathrm{ml})$ and $6 \mathrm{~N} \mathrm{HCl}$ $(20 \mathrm{ml})$ was heated under reflux for $30 \mathrm{~min}$ before dilution with water. Crystalline precipitate was filtered and recrystallized from $\mathrm{AcOH}$ to give $\mathbf{1 5 b}$ $(1.7 \mathrm{~g}, 91 \%), \mathrm{mp}>280^{\circ} \mathrm{C}$. Anal. Calcd for $\mathrm{C}_{17} \mathrm{H}_{13} \mathrm{NO}_{7} \mathrm{~S}: \mathrm{C}, 54.40 ; \mathrm{H}, 3.49$; $\mathrm{N}, 3.73$. Found: C, 54.34; $\mathrm{H}, 3.35 ; \mathrm{N}, 3.67$

Amides (16a-c) of 15b Phosphorus oxychloride (4.6 g, $30 \mathrm{mmol})$ was added dropwise to a stirred and cooled (between -5 and $-10^{\circ} \mathrm{C}$ ) suspen- 
sion of $15 \mathbf{b}(3.8 \mathrm{~g}, 10 \mathrm{mmol})$ in DMF $(75 \mathrm{ml})$. After continued stirring at the same temperature for $3 \mathrm{~h}$, the mixture was added dropwise to $25 \% \mathrm{NH}_{4} \mathrm{OH}$ at $10-20^{\circ} \mathrm{C}$. After $30 \mathrm{~min}$, the whole was acidified to $\mathrm{pH} 4$ with $4 \mathrm{~N} \mathrm{HCl}$ to precipitate crude 16a, which was recrystallized from $\mathrm{AcOH}, \mathrm{mp} 251-$ $253{ }^{\circ} \mathrm{C}(2.8 \mathrm{~g}, 75 \%)$. Anal. Calcd for $\mathrm{C}_{17} \mathrm{H}_{14} \mathrm{~N}_{2} \mathrm{O}_{6} \mathrm{~S}: \mathrm{C}, 54.54 ; \mathrm{H}, 3.77$; N 7.48. Found: C, 54.32; H, 3.77; N, 7.70. Compounds $16 \mathbf{b}$ and $\mathbf{1 6 c}$ were obtained using the same amidation procedure.

16b, mp $255-256^{\circ} \mathrm{C}$ after recrystallization from EtOH. Anal. Calcd for $\mathrm{C}_{18} \mathrm{H}_{16} \mathrm{~N}_{2} \mathrm{O}_{6} \mathrm{~S}: \mathrm{C}, 55.66 ; \mathrm{H}, 4.15 ; \mathrm{N}, 7.21$. Found: $\mathrm{C}, 55.86 ; \mathrm{H}, 4.37 ; \mathrm{N}, 7.25$.

$16 \mathrm{c}, \mathrm{mp} 213-215^{\circ} \mathrm{C}$ after recrystallization from AcOEt. Anal. Calcd for $\mathrm{C}_{19} \mathrm{H}_{18} \mathrm{~N}_{2} \mathrm{O}_{6} \mathrm{~S}: \mathrm{C}, 56.71 ; \mathrm{H}, 4.51 ; \mathrm{N}, 6.96$. Found: $\mathrm{C}, 56.73 ; \mathrm{H}, 4.51 ; \mathrm{N}, 6.88$.

$\mathrm{N}$-(3-Amino-4-oxo-6-phenoxy-4H-7-chromenyl)methanesulfonamide (18) and Fluorinated 6-Phenoxy Analogues (21a-d) Bromine (16.3 g, $0.10 \mathrm{~mol}$ ) was added over $30 \mathrm{~min}$ to a stirred solution of $2(33.3 \mathrm{~g}, 0.10 \mathrm{~mol})$ in $\mathrm{CHCl}_{3}(300 \mathrm{ml})$ which was maintained at $25-30^{\circ} \mathrm{C}$. After continued stirring at the same temperature for $30 \mathrm{~min}$, the reaction mixture was treated with water $(100 \mathrm{ml})$. The organic phase was successively washed with $5 \%$ $\mathrm{Na}_{2} \mathrm{~S}_{2} \mathrm{O}_{3}$, water and brine, then dried on $\mathrm{MgSO}_{4}$ and concentrated. The residual 3-bromo compound $17(40.1 \mathrm{~g}, 97 \%)$ showed $\mathrm{mp} 144-145.5^{\circ} \mathrm{C}$ and IR $(\mathrm{KBr}) 1680 \mathrm{~cm}^{-1}$ after recrystallization from toluene. The crude bromide $(40.1 \mathrm{~g})$ was dissolved in DMF $(280 \mathrm{ml})$, and $\mathrm{NaN}_{3}(13.9 \mathrm{~g}, 0.21 \mathrm{~mol})$ was added before heating at $70-75^{\circ} \mathrm{C}$ under stirring for $1 \mathrm{~h}$. The reaction mixture was cooled and poured into a mixture of AcOEt $(1500 \mathrm{ml})$ and $\mathrm{H}_{2} \mathrm{O}$ $(300 \mathrm{ml})$, then the whole was acidified $(\mathrm{pH}<1)$ with $\mathrm{HCl}$. The aqueous layer was separated and, after washing with AcOEt, was made $\mathrm{pH} 4$ with $10 \%$ $\mathrm{NaOH}$ and extracted with AcOEt. The AcOEt solution was washed with water, dried on $\mathrm{MgSO}_{4}$, and concentrated. The residual solid was recrystallized from EtOH to give $18(27.7 \mathrm{~g}, 80 \%), \mathrm{mp} 162-163^{\circ} \mathrm{C}$. ' $\mathrm{H}-\mathrm{NMR}$ $\left.(60 \mathrm{MHz} \text { in DMSO-d })_{6}\right) \delta: 3.19(3 \mathrm{H}, \mathrm{s}), 5.50-7.00(2 \mathrm{H}, \mathrm{br}), 7.04-7.49$ $(5 \mathrm{H}, \mathrm{m}), 7.35(1 \mathrm{H}, \mathrm{s}), 7.62(1 \mathrm{H}, \mathrm{s}), 7.94(1 \mathrm{H}, \mathrm{s})$. Anal. Calcd for $\mathrm{C}_{16} \mathrm{H}_{14} \mathrm{~N}_{2} \mathrm{O}_{5} \mathrm{~S}: \mathrm{C}, 55.48 ; \mathrm{H}, 4.07 ; \mathrm{N}, 8.09$. Found: $\mathrm{C}, 55.46 ; \mathrm{H}, 4.00 ; \mathrm{N}, 7.91$.

The following 3 -amino chromones were prepared from $8 \mathbf{a}-\mathbf{d}$ using the same 3-step sequence of reactions: catalytic hydrogenation; bromination, and azidation (the yields refer to those based on the 2,3-dihydro intermediates $\mathbf{2 0 a}-\mathbf{d})$

$\mathrm{N}$-[3-Amino-4-oxo-6-(2-fluorophenoxy)-4H-7-chromenyl]methanesulfonamide (21a): $\mathrm{mp} 173-174^{\circ} \mathrm{C}$ after recrystallization from iso- $\mathrm{Pr}_{2} \mathrm{O}-\mathrm{AcOE}$ (75\% yield). Anal. Caled for $\mathrm{C}_{16} \mathrm{H}_{13} \mathrm{FN}_{2} \mathrm{O}_{5} \mathrm{~S}: \mathrm{C}, 52.75 ; \mathrm{H}, 3.60 ; \mathrm{N}, 7.69$. Found: C, 52.95; H, 3.71; N, 7.85.

$\mathrm{N}$-[3-Amino-4-oxo-6-(3-fluorophenoxy)-4H-7-chromenyl]methanesulfonamide (21b): mp $207-208^{\circ} \mathrm{C}$ after recrystallization from EtOH $(68 \%$ yield). Anal. Calcd for $\mathrm{C}_{16} \mathrm{H}_{13} \mathrm{FN}_{2} \mathrm{O}_{5} \mathrm{~S}: \mathrm{C}, 52.75 ; \mathrm{H}, 3.60 ; \mathrm{N}, 7.69$. Found: $\mathrm{C}$, $52.79 ; \mathrm{H}, 3.56 ; \mathrm{N}, 7.55$

$\mathrm{N}$-[3-Amino-4-oxo-6-(4-fluorophenoxy)-4H-7-chromenyl]methanesulfonamide (21c): $\mathrm{mp} 204-206^{\circ} \mathrm{C}$ after recrystallization from EtOH $(72 \%$ yield). Anal. Calcd for $\mathrm{C}_{16} \mathrm{H}_{13} \mathrm{FN}_{2} \mathrm{O}_{5} \mathrm{~S}: \mathrm{C}, 52.75 ; \mathrm{H}, 3.60 ; \mathrm{N}, 7.69$. Found: $\mathrm{C}$, $52.96 ; \mathrm{H}, 3.55 ; \mathrm{N}, 7.91$.

$\mathrm{N}$-[3-Amino-4-oxo-6-(2,4-difluorophenoxy)-4H-7-chromenyl]methanesulfonamide (21d): $\mathrm{mp} 202-202.5^{\circ} \mathrm{C}$ after recrystallization from $\mathrm{EtOH}$ (55\% yield). Anal. Calcd for $\mathrm{C}_{16} \mathrm{H}_{12} \mathrm{~F}_{2} \mathrm{~N}_{2} \mathrm{O}_{5} \mathrm{~S}: \mathrm{C}, 50.26 ; \mathrm{H}, 3.16 ; \mathrm{N}, 7.33$. Found: C, 50.13; H, 3.06; N, 7.42.

$\mathrm{N}$-(3-Formylamino-4-ox0-6-phenoxy-4H-7-chromenyl)methanesulfonamide $(19 \mathrm{a}=\mathrm{T}-614) \quad$ Acetic formic anhydride, prepared in situ by heating a mixture of $\mathrm{HCO}_{2} \mathrm{H}(27.6 \mathrm{~g}, 0.60 \mathrm{~mol})$ and $\mathrm{Ac}_{2} \mathrm{O}(30.6 \mathrm{~g}, 0.30 \mathrm{~mol})$ at $40-$ $45^{\circ} \mathrm{C}$ for $1.5 \mathrm{~h}$, was added to a solution of $18(34.6 \mathrm{~g}, 0.10 \mathrm{~mol})$ in $\mathrm{CH}_{2} \mathrm{Cl}_{2}$ $(400 \mathrm{ml})$, and the solution was stirred at room temperature for $1 \mathrm{~h}$ before addition of iso- $\mathrm{Pr}_{2} \mathrm{O}$. The precipitate was collected by filtration and recrystallized from $\mathrm{MeCN}$ to give $19 \mathrm{a}(27.3 \mathrm{~g}, 73 \%), \mathrm{mp} 236-238^{\circ} \mathrm{C} .{ }^{1} \mathrm{H}-\mathrm{NMR}$ $\left(400 \mathrm{MHz}\right.$ in DMSO- $\left.d_{6}\right) \delta: 3.22\left(3 \mathrm{H}, \mathrm{s}, \mathrm{CH}_{3} \mathrm{SO}_{2}\right), 7.15(2 \mathrm{H}, \mathrm{dd}, J=8.5,1.0$ $\left.\mathrm{Hz}, \mathrm{H}-2^{\prime}\right), 7.25\left(1 \mathrm{H}, \mathrm{tt}, J=7.5,1.0 \mathrm{~Hz}, \mathrm{H}-4^{\prime}\right), 7.32(1 \mathrm{H}, \mathrm{s}, \mathrm{H}-8), 7.47(2 \mathrm{H}$, dd, $\left.J=8.7,7.5 \mathrm{~Hz}, \mathrm{H}-3^{\prime}\right), 7.70(1 \mathrm{H}, \mathrm{s}, \mathrm{H}-5), 8.32(1 \mathrm{H}, \mathrm{d}, J=1.5 \mathrm{~Hz}, \mathrm{CHO})$, $9.27(1 \mathrm{H}, \mathrm{s}, \mathrm{H}-2), 9.79(1 \mathrm{H}$, br s, $\mathrm{N} \underline{\mathrm{HCHO}}), 10.05\left(1 \mathrm{H}, \mathrm{s}, \mathrm{N}_{\mathrm{HSO}} \mathrm{Me}\right) .{ }^{13} \mathrm{C}-$ NMR $\left(100 \mathrm{MHz}\right.$ in DMSO- $\left.d_{6}\right) \delta: 40.59\left(\mathrm{CH}_{3} \mathrm{SO}_{2}\right), 108.85(\mathrm{C}-5), 111.00(\mathrm{C}-$ 8), 117.61 (C-4a), $119.48\left(\mathrm{C}-2^{\prime}\right), 123.09$ (C-3), 124.53 (C-4'), 130.12 (C$\left.3^{\prime}\right), 135.27$ (C-7), 145.52 (C-2), 145.66 (C-6), 151.38 (C-8a), 155.47 (C-1'), 160.34 (CHO), $169.69(\mathrm{C}-4)$

Compounds $22 \mathrm{a}-\mathbf{d}$ were prepared from the corresponding phenoxy precursors $(21 \mathbf{a}-\mathbf{d})$ according to the same $\mathrm{N}$-formylation procedure, and $\mathrm{N}$ acetyl and $N$-benzoyl derivatives of $\mathbf{1 8}(\mathbf{1 9 b}, \mathbf{c})$ were obtained using $\mathrm{Ac}_{2} \mathrm{O}$ and $\mathrm{C}_{6} \mathrm{H}_{5} \mathrm{COCl}$, respectively. The characterization data of $19 \mathbf{a}-\mathbf{c}$ and $\mathbf{2 2 a}-$ d are given in Table 5 .

A Preparative-scale Synthesis of 19a (T-614) Aluminum chloride $(109 \mathrm{~g}, 0.82 \mathrm{~mol})$ and then $\mathrm{H}_{2} \mathrm{NCH}_{2} \mathrm{CN} \cdot \mathrm{HCl}(37.9 \mathrm{~g}, 0.41 \mathrm{~mol})$ were added portionwise to a stirred nitrobenzene $(300 \mathrm{ml})$ at room temperature. After being stirred at $40^{\circ} \mathrm{C}$ for $1 \mathrm{~h}$, the mixture was cooled to $10^{\circ} \mathrm{C}$ and treated with $4(100 \mathrm{~g}, 0.34 \mathrm{~mol})$, followed by saturation of the whole with dry $\mathrm{HCl}$ over the period of $10 \mathrm{~h}$ at the temperature of $25-30^{\circ} \mathrm{C}$. The reaction mixture was poured into ice-cooled $4 \mathrm{~N} \mathrm{HCl}(500 \mathrm{ml})$, and the precipitated solid product was filtered, washed successively with AcOEt and 2-propanol, and dried to give the semi-hydrate of $N$-[4-(2-aminoacetyl)-5-methoxy-2-phenoxyphenyl]methanesulfonamide hydrochloride (23) (122 g, 90\%), which was used for the next step without further purification. An analytical sample was obtained by recrystallization from aqueous acetone, $\mathrm{mp} 167-169.5^{\circ} \mathrm{C}$ (decomp.), IR (KBr) $1675 \mathrm{~cm}^{-1}$. Anal. Calcd for $\mathrm{C}_{16} \mathrm{H}_{19} \mathrm{ClN}_{2} \mathrm{O}_{5} \mathrm{~S} \cdot 0.5 \mathrm{H}_{2} \mathrm{O}$ : C48.54; H, 5.09; N, 7.09. Found: C, 48.48; H, 5.13; N, 6.95 .

Sodium formate $(41.2 \mathrm{~g}, 0.61 \mathrm{~mol})$ was added to a solution of trimethylacetyl chloride $(36.6 \mathrm{~g}, 0.30 \mathrm{~mol})$ in acetone $(300 \mathrm{ml})$, and the mixture was vigorously stirred at room temperature for $5 \mathrm{~h}$ before addition of $\mathbf{2 3}(100 \mathrm{~g}$, $0.25 \mathrm{~mol})$ and continued stirring for $3 \mathrm{~h}$. Water $(900 \mathrm{ml})$ was added to the reaction mixture, and the crystalline precipitate was filtered, washed with water and 2-propanol, and dried to give $N$-[4-(2-formylaminoacetyl)-5methoxy-2-phenoxyphenyl]methanesulfonamide (24) $(87 \mathrm{~g}, 91 \%)$, which was used for the next step without purification. An analytical sample was obtained by recrystallization from $\mathrm{MeCN}, \mathrm{mp} 153-154^{\circ} \mathrm{C}$, IR (KBr) 1679 , $1655 \mathrm{~cm}^{-1}$. Anal. Calcd for $\mathrm{C}_{17} \mathrm{H}_{18} \mathrm{~N}_{2} \mathrm{O}_{6} \mathrm{~S}: \mathrm{C}, 53.96 ; \mathrm{H}, 4.79 ; \mathrm{N}, 7.40$. Found: C, $54.07 ; \mathrm{H}, 4.81 ; \mathrm{N}, 7.48$.

Sodium iodide $(43.6 \mathrm{~g}, 0.29 \mathrm{~mol})$ and $24(100 \mathrm{~g}, 0.26 \mathrm{~mol})$ were added to a solution of $\mathrm{AlCl}_{3}(70.5 \mathrm{~g}, 0.53 \mathrm{~mol})$ in $\mathrm{MeCN}(300 \mathrm{ml})$ which was prepared at a temperature below $20^{\circ} \mathrm{C}$ by cooling with ice-water. After being stirred at $20^{\circ} \mathrm{C}$ for $3 \mathrm{~h}$, the reaction mixture was poured into $1 \%$ aqueous $\mathrm{Na}_{2} \mathrm{SO}_{3}$ $(900 \mathrm{ml})$, and the pale yellow precipitate was filtered, washed with water and $\mathrm{EtOH}$, and air-dried to obtain $N$-[4-(2-formylaminoacetyl)-5-hydroxy-2-phenoxyphenyl]methanesulfonamide (25) $(91.5 \mathrm{~g}, 95 \%), \mathrm{mp} 173-174.5^{\circ} \mathrm{C}$ after recrystallization from $\mathrm{MeCN}, \mathrm{IR}(\mathrm{KBr}) 1664,1639 \mathrm{~cm}^{-1}$. Anal. Calcd for $\mathrm{C}_{16} \mathrm{H}_{16} \mathrm{~N}_{2} \mathrm{O}_{6} \mathrm{~S}$ : C, 52.74; H, 4.43; N, 7.69. Found: C, 52.74; H, 4.32; N, 7.46

$N, N$-Dimethylformamide dimethylacetal $(40.9 \mathrm{~g}, 0.34 \mathrm{~mol})$ was added to a stirred solution of $25(50.0 \mathrm{~g}, 0.14 \mathrm{~mol})$ in DMF $(150 \mathrm{ml})$ at $10^{\circ} \mathrm{C}$, and the mixture was stirred at $15^{\circ} \mathrm{C}$ for $8 \mathrm{~h}$ before addition of $\mathrm{CH}_{2} \mathrm{Cl}_{2}(250 \mathrm{ml})$ and water $(500 \mathrm{ml})$. The insoluble crystalline material was filtered, washed successively with $\mathrm{CH}_{2} \mathrm{Cl}_{2}(150 \mathrm{ml})$, water $(150 \mathrm{ml})$ and $\mathrm{EtOH}(150 \mathrm{ml})$, then dried to give $19 \mathrm{a}$ (T-614) $(44.4 \mathrm{~g}, 87 \%), \mathrm{mp} 236-238^{\circ} \mathrm{C}$ after recrystallization from $\mathrm{MeCN}$, which was identical with a sample prepared by $\mathrm{N}$-formylation of 18

Pharmacological Methods The carrageenin-induced rat paw edema assay was carried out using procedures described by Winter et al. and Otterness and Moore. ${ }^{22)}$ Assessment of therapeutic and prophylactic effects on rat adjuvant arthritis was carried out according to the method of Pearson. ${ }^{23 a)}$ Collagen arthritis was induced in male DBA/ $1 \mathrm{~J}$ mice by a modification of the method described by Wooley. ${ }^{24)}$ Gastro-ulcerogenic study in rats was performed according to the experimental procedures detailed by Ono and co-workers ${ }^{25}$ and the lesion index (L. I.) was calculated by the method originally described by Robert $e t a l .{ }^{17 a)}$ All test samples were prepared as fine suspensions by homogenizing the finely powdered samples in $0.5 \%$ carboxymethylcellulose sodium (CMC-Na, Tokyo Kasei) and were administered orally via a gavage needle.

Inhibition of Carrageenin-Induced Paw Edema in Rats Male Donryu rats $(100-130 \mathrm{~g})$, fasted overnight with free access to water, were given orally via a gavage needle either the vehicle $(0.5 \%$ aqueous $\mathrm{CMC}-\mathrm{Na})$ or a test compound $(10 \mathrm{mg} / \mathrm{kg})$ suspended in the same solvent $(1.0 \mathrm{ml} / 100 \mathrm{~g}$ body weight). One hour later, a $1 \%$ solution of Seakem- 402 carrageenin (Marine Colloids, Springfield, NJ) in sterile saline $(0.1 \mathrm{ml})$ was injected into the plantar surface of the left hindpaw. Three hours after the irritant injection, the paw volume was measured using a plethysmometer. The increase in paw volume was compared with that in the vehicle control group to calculate inhibition \%. The data shown are those obtained on the basis of the average of 6 or 7 rats. The $\mathrm{ED}_{30}$ values were determined by a linear regression analysis using the data with three to five doses.

Inhibition of Adjuvant-Induced Arthritis in Rats Adjuvant arthritis was induced in male Lewis rats (7-week-old, $150-170 \mathrm{~g}$ ) by intradermal injection of a suspension of heat-killed Mycobacterium tuberculosis (Difco Laboratories) in mineral oil $(0.6 \mathrm{mg} / 0.1 \mathrm{ml})$ at the base of the tail. Eighteen days after the adjuvant injection, animals showing typical inflammation in the hindpaws were grouped ( $n=5$ or 6$)$ and received once daily oral administration of a test compound $(10 \mathrm{mg} / \mathrm{kg})$ suspended in $0.5 \%$ aqueous CMC$\mathrm{Na}(1.0 \mathrm{ml} / 100 \mathrm{~g}$ body weight) over a period of $4 \mathrm{~d}$ (for \% reduction) or $7 \mathrm{~d}$ (for $\mathrm{ED}_{40}$ values). Twenty-four hours after the last dosing, the volumes of both hindpaws were measured using a plethysmometer to obtain inhibition 
$\%$ in comparison to vehicle-treated controls. For the assessment of prophylactic effects, once daily oral administration of a test compound ( 0.3 or $3.0 \mathrm{mg} / \mathrm{kg}$ ) to rats ( 5 or 6 animals per group) started shortly after the adjuvant injection and continued over the period of $22 \mathrm{~d}$.

Gastric Ulcerogenicity in Rats Male Wistar rats of $180-200 \mathrm{~g}$ ( 7 or 8 rats per group) were fasted for $24 \mathrm{~h}$ with free access to water before receiving oral administration of a test compound or solvent vehicle (CMC-Na). After continued fast for $5 \mathrm{~h}$ without water supply, the rats were sacrificed by carbon dioxide inhalation. The stomachs were removed and fixed with $1 \%$ formalin for $30 \mathrm{~min}$ before opening along the greater curvature and rinsing with tap water. The mucosa was examined for the presence of lesions using a stereoscopic microscope. Severity of lesions was graded according to the following score scales $(0$ to 4 ): $0=$ normal; $1=$ petechiae; $2=$ a lesion smaller than $1 \mathrm{~mm}$ in length; $3=$ a lesion between 1 and $3 \mathrm{~mm}$ in length; $4=\mathrm{a}$ lesion greater than $3 \mathrm{~mm}$ in length. A total severity score for each rat was calculated by multiplying the number of lesions by their severity rating and summing the products. The $\mathrm{UD}_{50}$ value, the dose that caused gastric lesions of the scores $\geq 2$ in $50 \%$ of the animals, was calculated by the method of Litchfield and Wilcoxon. ${ }^{26)}$ The L. I., an overall assessment of damage, was calculated by the method of Robert and others, ${ }^{17)}$ which is the sum of (1) average number of lesions, (2) average severity of lesions, and (3) \% incidence divided by 10 .

Collagen-Induced Arthritis in Mice Male DBA/1 J mice (8-week-old, $n=7$ per group; Charles River, Japan) were primed by an intradermal injection at several sites of the hip with $0.2 \mathrm{ml}$ of an emulsion consisting of equal volumes of Freund's complete adjuvant (FCA) (Nacalai Tesque, Kyoto) and bovine type II collagen of $2 \mathrm{mg} / \mathrm{ml} 0.1 \mathrm{M}$ acetic acid (Funakoshi, Tokyo). After 3 weeks, the mice received a booster of the same amount of the $\mathrm{FCA}$ /collagen emulsion $(0.2 \mathrm{ml})$ as given in the primary immunization, followed by once daily oral dosing for 2 weeks. The arthritis scores of 0 to 3 were determined on day 35 according to the following criteria: $0=$ noninvolved; $1=$ swelling of one or two toes, or slight swelling of the ankle; $2=$ swelling of one or two toes accompanied by slight swelling of the ankle, or moderate swelling of the ankle; $3=$ extensive swelling of the paws. The maximum possible score for an arthritic mouse was 12 (3 points for each paw). For joint-degeneration study, the paws were cut off after bleeding at ca. $8 \mathrm{~mm}$ above the wrist and ankle joints and subjected to radiographic analysis using an X-ray apparatus (SOFTEX-cmbw, Softex, Tokyo): exposure of the paw samples placed on X-ray films (Fuji FR, $12 \times 16.5 \mathrm{~cm}$ ) with $36 \mathrm{kV}$ and $10 \mathrm{~mA}$ for $8 \mathrm{~s}$ at the distance of $64 \mathrm{~cm}$. The films were inspected for the 42 joints per mouse, which are connected with the following bones: forepaw bones of carpus, five metacarpals, and four proximal phalanges ( 2 nd to 5 th); hindpaw bones of calcaneus, tarsal, five metacarpals, and four proximal phalanges ( 2 nd to 5 th). The counting of affected joints (maximum possible score of 42 per mouse) was performed by two persons not aware of the experimental procedures.

Serum IL-6 assay was performed with the mice receiving a sample-dosing for 34 consecutive days starting on day 0 . Blood samples were collected on day 35 via interior vena cava under ether-anesthesia and kept at $-30^{\circ} \mathrm{C}$ in a freezer before use. Concentration of IL-6 was determined using a mouse ELISA kit (BioSource International) and according to the instructions provided by the regent supplier.

Acknowledgment The authors are grateful to Professor Emeritus E. Yoshii of Toyama Medical and Pharmaceutical University for his help and useful suggestions in the preparation of the manuscript.

\section{References and Notes}

1) Insel P. A., "Goodman \& Gilman's The Pharmacological Basis of Therapeutics," 9th ed., ed. by Hardman J. G., Gilmann A. G., Limbirt L. E., McGraw-Hill, 1996, Chapter 27, pp. 617-657.

2) a) Swingle K. F., Moore G. G. I., Grant T. J., Arch. int. Pharmacodyn., 221, 132 -139 (1976); b) Biscarini L, Patoia L., Del Favero A., Drugs Today, 24, 23-27 (1988); c) Swingle K. F., Moore G. G. I., Drugs Expt. Clin. Res., 10, 587-597 (1984); d) Ward A., Brogden R. N., Drugs, 36, 732-753 (1988).

3) a) Rufer C., Bahlmann F., Schröder E., Böttcher I., Eur. J. Med. Chem., 17, 173-180 (1982); b) Böttcher I., Schweizer A., Glatt M., Werner H., Drugs Exp. Clin. Res., 13, 237-245 (1987); c) Wiesenberg-Boettcher I., Schweizer A., Green J. R., Mueller K., Maerki F.,
Pfeilschifter J., ibid., 15, 501-509 (1989); d) Wiesenberg-Böttcher I., Schweizer A., Green J. R., Seltenmeyer Y., Müller K., Agents Actions, 26, 240-242 (1989); e) Hirschelmann R., Hentschel M., Giessler J., Rickinger O., ibid., 32, 54-55 (1991).

4) Futaki N., Yoshikawa K., Hamasaka Y., Arai I., Higuchi S., Iizuka H., Otomo S., Gen. Pharmacol., 24, 105-110 (1993).

5) a) Tsuji K., Nakamura K., Konishi N., Okumura H., Matsuo M., Chem. Pharm. Bull., 40, 2399-2409 (1992); b) Nakamura K., Tsuji K., Konishi N., Okumura H., Matsuo M., ibid., 41, 894-906 (1993).

6) Griswold D. E., Adams J. L., Med. Res. Rev., 16, 181-206 (1996).

7) Preliminary communications dealing with antiinflammatory and related properties of T-614 itself have been reported. Tanaka K., Shimotori T., Makino S., Aikawa Y., Inaba T., Yoshida C., Takano S., Arzneimittelforschung, 42, 935-944 (1992); Tanaka K., Makino S., Shimotori T., Aikawa Y., Inaba T., Yoshida C., ibid., 42, 945-950 (1992).

8) Schröder E., Lehmann M., Rufer C., Böttcher I., EP 59884 [Chem. Abstr, 98, 71912h (1983)].

9) Becket G. J. P., Ellis G. P., Trindade M. I. U., J. Chem. Res. $(S), \mathbf{1 9 7 8 ,}$ 47.

10) Ellis G. P., Chem. Heterocycl. Compd., 31, 515-526 (1977).

11) a) Mozingo R., Org. Synth., Coll. Vol., 3, 387-390 (1955); b) Hepworth J. D., "Comprehensive Heterocyclic Chemistry," Vol. 3, ed. by Boulton A. J., McKillop A., Pergamon Press, 1984, pp. 816-817.

12) Ellis G. P., Thomas I. L., J. Chem. Soc., Perkin I, 1974, 2570-2574.

13) Föhlisch B., Chem. Ber., 104, 348-349 (1971).

14) a) Szabo V., Nemeth L., Magy. Kem. Foly., 84, 164-166 (1978) [Chem. Abstr. 89, 43022p (1978)]; b) DeWald H. A., Heffner T. G., Jaen J. C., Lustgarten D. M., McPhail A. T., Meltzer L. T., Pugsley T. A., Wise L. D., J. Med. Chem., 33, 445-450 (1990).

15) a) Asscher M., Rec. Trav. Chim., 68, 960-968 (1949); b) Moed H. D., Asscher M., Van Draanen P. J. A., Niewing H., ibid,, 71, 933-944 (1952); Chem. Abstr., 49, $12357 b$ (1955).

16) Node M., Ohta K., Kajimoto T., Nishide K., Fujita E., Fuji K., Chem. Pharm. Bull., 31, 4178-4180 (1983).

17) a) Robert A., Nezamis J. E., Phillips J. P., Gastroenterology, 55, 481487 (1968); b) Rainsford K. D., Agents Actions, 5, 553-558 (1975); c) Idem, ibid., 7, 573-577 (1977).

18) Takai Y., Seki N., Senoh H., Yokota T., Lee F., Hamaoka T., Fujiwara H., Arthritis Rheum., 32, 594-600 (1989). For the role of IL-6 in the pathogenesis of collagen-induced arthritis, see: Takagi N., Mihara M., Moriya Y., Nishimoto N., Yoshizaki K., Kishimoto T., Takeda Y., Ohsugi Y., ibid., 41, 2117-2121 (1998). For in vitro inhibitory activity of T-614 in releasing IL-6 and IL- $1 \beta$ from lipopolysaccharide-stimulated THP-1 cells, see: Tanaka K., Aikawa Y., Kawasaki H., Asaoka K., Inaba T., Yoshida C., J. Pharmacobio-Dyn., 15, 649-655 (1992)

19) The following COX-inhibitory data were obtained using enzymes from ram seminal vesicles (COX-1) and sheep placenta (COX-2): COX$1 / \mathrm{COX}-2\left(\mathrm{COX}-2, \mathrm{IC}_{50} \mu \mathrm{M}\right)$ : indomethacin $=0.27(0.34)^{20)} ; 19 \mathrm{a}=>40$ $(20)^{20)}$; nimesulide $=25$ (18) (unpublished data). The COX-2 selectivity of $19 a$ is greater than that of nimesulide, but the difference is marginal to ascribe the overwhelming ulcerogenic safety of 19a (Table 2) to its COX-2 selectivity only.

20) Tanaka K., Kawasaki H., Kurata K., Aikawa Y., Tsukamoto Y., Inaba T., Jpn. J. Pharmacol., 67, 305--314 (1995).

21) Edmonds J. P., Scott D. L., Furst D. E., Brooks P., Paulus H. E., Arthritis Rheum., 36, 336-339 (1993).

22) a) Winter C. A., Risley E. A., Nuss G. W., Proc. Soc. Exp. Biol. Med., 111, $544-547$ (1962); b) Otterness I. G., Moore P. F., Methods Enzymol., 162, 320-327 (1988).

23) a) Pearson C. M., Proc. Soc. Exp. Biol. Med., 91, 95-101 (1956); b) Taurog J. D., Argentieri D. C., McReynolds R. A., Methods Enzymol., 162, $339-355$ (1988); c) Jaffee B. D., Kerr J. S., Jones E. A., Giannaras J. V., McGowan M., Ackerman N. R., Agents Actions, 27, 344 346 (1989).

24) Wooley P. H., Methods Enzymol., 162, 361-373 (1988).

25) Ono N., Yamasaki Y., Yamamoto N., Sunami A., Miyake H., Folia Pharmacol. Jpn, 88, 205-213 (1986).

26) Litchfield J. T., Wilcoxon F., J. Pharmacol. Exp. Ther., 96, 99-113 (1949). 